Archives of Agriculture and Environmental Science

\title{
A review on feasibility of phytoremediation technology for heavy metals removal
}

\section{Vinod Kumar and Piyush Kumar*}

Agro-ecology and Pollution Research Laboratory, Department of Zoology and Environmental Science, Gurukula Kangri Vishwavidyalaya, Haridwar-249404 (Uttarakhand), INDIA

"Corresponding author's E-mail: kumarpiyushgkv@gmail.com

\section{ARTICLE HISTORY}

Received: 22 July 2019

Revised received: 26 August 2019

Accepted: 06 September 2019

\section{Keywords}

Contamination

Eco-Friendly

Heavy metals

Hyperaccumulators

Industrialization

Phytoremediation

\begin{abstract}
Quick jump of urbanization and industrialization is responsible for birth of heavy metal pollution. In the aquatic systems, heavy metals are one of the most dangerous pollutants that may be found. It can have both natural and anthropogenic origins. In aquatic ecosystem heavy metal pollution have a serious hazard to biodiversity of aquatic ecosystems, and drinking polluted water contaminated with heavy metals can have severe health risks in humans as well as in all living-beings. The commercial characteristics and side effects of conservative treatment equipment in aquatic environment flagged the way to eco-sustainable technology like phytoremediation. In phytoremediation, Plants are used to clean up the environment from numerous dangerous contaminants. Phytoremediation is cost-effective and ecofriendly expertise for environmentally friendly cleanup. The present review reflects the characteristics of heavy metals and possible environmental threats together with this, review also inspects the role played by the macrophytes in phytoremediation studies in the recent past. In the reduction of heavy metal contamination in aquatic environments which receive the industrial discharges and municipal wastewater, aquatic macrophytes are powerful tools to remediate them.
\end{abstract}

(c)2019 Agriculture and Environmental Science Academy Citation of this article: Kumar, V. and Kumar, P. (2019). A review on feasibility of phytoremediation technology for heavy metals removal. Archives of Agriculture and Environmental Science, 4(3): 326-341, https://dx.doi.org/10.26832/24566632.2019.0403011

\section{INTRODUCTION}

Fast industrialization and urbanization have ended in multiplied emission of toxic heavy metals getting into the biosphere (Gazsó, 2001). Activities together with mining and agriculture have polluted good sized regions throughout the sector (Smith et al., 1996; Shallari et al., 1998). Earth's crust is the home for metals where they are found naturally. The composition of metals varies from locality to locality, resulting in spatial differences of surrounding concentrations (Jaishankar et al., 2014). In waste water the generally present heavy metals are arsenic, copper, cadmium, chromium lead, nickel, and zinc, which are quite toxic and have potential risks for human health and the environment (Lambert et al., 2000). The release of heavy metals in biologically to be had forms with the aid of human interest, may additionally damage or modify each herbal and man-made ecosystems (Taylor et al., 1989).
Heavy metal ions consisting of $\mathrm{Cu}^{2+}, \mathrm{Zn}^{2+}, \mathrm{Fe}^{2+}$ are vital micronutrients for plant metabolism however whilst found in excess, can emerge as extraordinarily toxic. Many heavy metals are categorized as precedence pollutants with the aid of US Environmental protection agency. Lead, mercury, arsenic, and cadmium ranked as first, second, third, and sixth risks at the listing from US Agency for Toxic Substances and Disease Registry (ATSDR) that lists all hazards present in toxic waste websites consistent with their occurrence and the severity in their toxicity. The heavy metals like $\mathrm{Cd}, \mathrm{Pb}, \mathrm{Co}, \mathrm{Zn}$ and $\mathrm{Cr}$ which are very common are phytotoxic at both low and very high concentration are found in waste water. If these metals reach in sediments then they got engaged in the food chain via aquatic plants and animals. In small portions, a few heavy metals are nutritionally important for a nourishing life, however large measures of any of the heavy metal may also cause toxicity (poisoning). In the recent past, 
there had been increasing a vast number of cases of heavy metallic pollutions in the environment reputedly because of poisonousness and superficial persistency of heavy metals inside the aquatic ecosystems (Tijani et al., 2005). Contamination by heavy metals is a worldwide stress, even though harshness and levels of pollutants differ from locality to locality. At least 20 metals are labeled as toxic with half of them emitted into the environment that poses huge risks to human health (Akpor and Muchie, 2010). Heavy metal polluted sites must be remediated to reduce the associated risks. Metals cannot be degraded like organic compounds and cleanup typically needs removal of heavy metals. Utmost of the conventional remediation techniques are costly and reduce the fertility of the soil; this afterwards would responsible for bad impacts on the environment (Kumar et al., 2016).

Phytoremediation is a budget operational, eco-friendly, artistically attractive approach best appropriate for developing countries like India. For applications in phytoremediation and phytomining, various effective metal hyperaccumulators are being discovered. Vegetation have the capacity to accumulate nonessential metals such as $\mathrm{Cd}$ and $\mathrm{Pb}$, and this capacity may be harnessed to do away with pollutant metals from the environment (Salt et al., 1995; Das et al., 1997; Rogers et al., 2000). Currently there is a large interest in growing inexpensive and environmental friendly technologies for the remediation of soil and wastewater polluted with hazardous heavy metals (Zayed et al., 1998). Plants based bioremediation technologies have obtained current interest as techniques to easy-up contaminated soil and water (Sadowsky, 1999). Many sorts of plants have been tested for phytoremediation, amongst various plant organisms, participants of Lemnaceae and Azollaceae have been documented as capacity accumulators of metals therefore may be utilised for the enrichment of water contamination to decrease the pollution load (Horvat et al., 2007; Rai, 2010). The submerged macrophytes are mainly beneficial within the abatement and tracking of heavy metals (Gupta and Chandra, 1998). Earlier works in the field of waste water treatment confirmed that aquatic macrophytes can be used to partially accumulate or absorb trace metals present in wastewaters (Chandra et al., 1993). The aquatic macrophytes suck/absorb heavy metals by the use of their floor adsorption and/or absorption and store them in a bonded form. Effluent treated by these macrophytes therefore becomes less toxic to the aquatic environment. At metals polluted locations, plants are used to stabilize and remove the metals from the soil and ground water through mechanisms such as phytoextraction, rhizofiltration, and phytostabilization (Kumar et al., 2019a).

The present review will be helpful to understand the concept of heavy metal sources, their harsh effects and need of their removal from contaminated sites. It would also explain the phytoremediation technology and its applications in remediation of heavy metals by different processes. The goal of this review is to give vision into the sources of heavy metals and their dangerous properties on the surroundings and living creatures and remediation strategies to get rid of them or to minimize their effects by the use of some hyper accumulator plants which usually absorb them and decrease their effects.

\section{CHARACTERISTICS OF HEAVY METALS}

\section{Arsenic (As)}

Although arsenic occurs as the $20^{\text {th }}$ most abundant element in the geosphere, arsenic is extremely poisonous to the biota. In many zones, arsenic levels in the environment have beaten the safe threshold for human welfare viz, $10 \mu \mathrm{g} / \mathrm{l}$. Its inorganic forms are poisonous to the environment and living beings such as arsenite and arsenate complexes. Humans may be exposed to arsenic by natural phenomenon unintended sources or from industrial sources (Jaishankar et al., 2014). Arsenic is very chief heavy metal causing anxiety at both ecological and individual health levels (Hughes et al., 1988). Arsenic displays poisonousness even at low exposures (Dikshit et al., 2000) and causes diseases like black foot (Lin et al. 1998). It is now well documented that ingestion of arsenic, even at low levels, leads to carcinogenesis (Mandal and Suzuki, 2002). Gastrointestinal indications such as severe vomiting, injury to the nervous system, disorders of the blood and circulation and ultimately death can be the result of consumption of large amounts of arsenic. Large doses of arsenic when not deadly, may break up red blood cells in the circulation, decrease blood cell production, color the skin, enlarge the liver, produce burning and loss of consciousness in the limbs, and also damage the brain (Mahurpawar, 2015).

\section{Cadmium (Cd)}

According to ATSDR ranking, Cadmium is the seventh most poisonous heavy metal. Cadmium is generated by zinc production as a by-product to which humans or animals may get exposed at labor or in the surroundings. It will accumulate inside the body throughout life if once gets absorbed by humans (Jaishankar et al., 2014). Because of its high rate of soil-to plant handover, Cadmium is largely found in vegetables and fruits (Satarug et al., 2011). Cadmium is an extremely poisonous unnecessary heavy metal which is well known for its adverse effect on the enzymatic systems of cells, oxidative pressure and for encouraging nutritive deficiency in plants (Irfan et al., 2013). Consumption for people is assessed as $0.15 \mu \mathrm{g}$ from air and $1 \mu \mathrm{g}$ from water for normal day by day. Inhalation and ingestion of cadmium by humans can affect the health but the main health impacts reported in the literature are through dietary exposure (kidney and bone damage) and inhalation by tobacco, smoking and work-related exposure (lung damage). The highest human organ affected by cadmium is the kidney in both the general population and the occupationally exposed (Mahurpawar, 2015). Smoking a packet of 20 cigarettes can prompt the inward inhalation of around 2-4 $\mathrm{g}$ of cadmium, due to which levels may on large scale (Clinton et al., 2014).

\section{Chromium ( $\mathrm{Cr}$ )}

Burning of oil and coal, petroleum from ferrocromate refractory material, catalyst, chromium steel, fertilizers, pigment oxidants, 
metal plating tanneries and oil well drilling are the natural sources of chromium occurrence. Chromium is discharged into the environment through waste material and fertilizers, anthropogenically (Ghani, 2011). Chromium is used on a large scale in industries like metallurgy, tanning, electroplating, paints production, pigments chemical manufacture and pulp and paper making. Oxygen is present in the environment in excess due to which, $\mathrm{Cr}$ (III) is oxidized to more toxic $\mathrm{Cr}(\mathrm{VI})$, which is tremendously poisonous and greatly soluble in water (Cervantes et al., 2001). In the capital of Japan, Tokyo, during August 1975, the underground water holding $\mathrm{Cr}$ (VI) spoil masses had a 2,000 times higher limit than the permissible limit of chromium (Zayed and Terry, 2003). The chromium level in underground water has been witnessed to be more than $12 \mathrm{mg} / \mathrm{L}$ and 550-1,500 ppm/L in India. (Jaishankar et al., 2014). The industrial wastes discharge and ground water pollution has harshly amplified the chromium concentration in the soil (Bielicka et al., 2005). The toxicity of chromium significantly affects the biological processes in several plants like maize, cauliflower, barley, citrullus and in vegetables. Chlorosis and Necrosis occurs in plants due to the chromium toxicity (Ghani, 2011).

\section{Mercury $(\mathrm{Hg})$}

The metallic mercury is a metal which occurs naturally and is a glossy silver-white, unscented fluid and winds up dull and $s$ centless gas when warmed. Mercury is exceptionally lethal and exceedingly bio-accumulative. Its presence unfavorably influences the marine condition and henceforth numerous studies are coordinated towards the spreading of mercury in water environment. Main sources of mercury contamination include anthropogenic activities such as agriculture, municipal wastewater discharges, mining and discharges of industrial wastewater (Chen et al., 2012). Real sources of mercury contamination incorporate anthropogenic exercises, for example, horticulture, municipal wastewater releases, mining, incineration, and releases of industrial wastewater (Chen et al., 2012). Mercury is widely utilized in thermometers, indicators, pyrometers, hydrometers, mercury circular segment lights, fluorescent lights and as a catalyst. It is additionally being utilized in pulp and paper businesses, as a part of batteries and in dental arrangements, for example, amalgams. Methyl mercury is a neurotoxic compound which is accountable for microtubule obliteration, mitochondrial harm, lipid peroxidation and accumulation of neurotoxic molecules, for example, serotonin, aspartate, and glutamate (Patrick, 2002). The mind remains the objective organ for mercury, yet it can damage any organ and prompt breaking down of nerves, kidneys and muscles. It can make interruption the membrane potential and interrupt intracellular calcium homeostasis. Mercury vapors can cause asthma, bronchitis, and transitory respiratory issues. Mercury assumes a key part in harming the tertiary and quaternary protein structure what's more, changes the cell work by joining to the selenohydryl and sulfhydryl bunches which experience response with methyl mercury and hamper the cell structure (Jaishankar et al., 2014).
Lead $(\mathrm{Pb})$

Lead is one of the very poisonous heavy metals that accumulate in individuals and affect the whole food chain and disturb the health system of animals, phytoplanktons and human beings. Lead reaches water system together with urban runoff and discharges as for example, sewage treatment plants and industrial plants. The primary sources of lead are Industrial processes of production and their discharges, operations of mining, smelting, combustion sources and solid waste incinerators and some other sources of lead are batteries, lead paint, lead piping used in water delivery system (Singh et al., 2011). Lead is a standout amongst the most noxious metals that have a serious risk to individuals, creatures and phytoplanktons. It can also disturb the kidney and most significantly the brain and nervous system and lead can accumulate over a lifespan and it causes diseases as for example anemia, hepatitis and nephritic syndrome, encephalopathy. It go beyond the WHO (2004) permissible standard $0.15 \mathrm{mg} / \mathrm{L}$ and continuous contact may lead to interruption in mental or physical growth in infants and youngsters though adults may have kidney complications and high blood pressure. The aquatic system is also influenced by lead in which young fish are more prone than adults or eggs.

\section{Iron (Fe)}

On the earth's crust, iron is the second preeminent abundant metal (EPA, 1993). Elemental position of Iron in the Periodic Table is $26^{\text {th }}$. For the development and survival of every living life form Iron is a standout amongst the most essential components (Valko et al., 2005). Men made activities such as mining exercises are the sources of iron in surface water. High acceptance of $\mathrm{Fe}^{2+}$ by roots, acropetal translocation process towards leaves, tanning of rice leaves and yield loss are incorporated in highlights of iron poisonousness (Becker and Asch, 2005). For different organic redox procedures because of its inter-conversion process amongst ferrous $\left(\mathrm{Fe}^{2+}\right)$ and ferric $\left(\mathrm{Fe}^{3+}\right)$ ions, iron is an appealing progress metal (Phippen et al., 2008). Rice generation is limited by the Corrosive soils and the cause of a macronutrient issue in wetland rice is $\mathrm{Zn}$ inadequacy. In flooded soils, the reduced iron $\left(\mathrm{Fe}^{2+}\right)$ present in great concentrations which affected the production of lowland rice tremendously. According to the study of Phippen et al. (2008), the poisoning effects of iron on water plants especially rice, reviled that the progression of species of aquatic reed was found to be restrained by convergence of $1 \mathrm{mg} / \mathrm{L}$ add up to iron. When the absorbed iron is not capable to bind with the protein, a varied kind of injurious free radicals are formed, which in mammalian cells and biological fluids, consecutively harshly affects the iron concentration (Jaishankar et al., 2014). Destructive effect on the abdominal tract and biological fluids are the fallouts of this circulatory unbound iron. Iron crosses the rate-constraining assimilation step and ends up saturated, when enters into the body in an extremely high level. These free irons enter into cells of the liver, mind and heart. Lipid peroxidation by the free iron results in severe injury to microsomes, mitochondria and other cellular organelles (Albretsen, 2006). 


\section{Zinc (Zn)}

Zinc has a significant role in numerous biological processes involving development of organisms and normal growth as it is a part of several metal- proteins and metal- enzymes (Zinicovscaia et al., 2018). Actuate oxidative pressure, destruction of DNA molecules, and also can lead to the impairment of growth and reproduction can happen if in any case, zinc is present in abundance in water (Finocchio et al., 2010; Zinicovscaia et al., 2015). In this way, the presence of zinc ions in wastewaters indicates a risk to the aquatic ecosystem and increases numerous perils for human beings (Finocchio et al., 2010). Effluents released from industries engaged in electroplating, galvanization, amalgam production are the frequent source of zinc and other sources of zinc are acid mine drainage, metropolitan wastewater treatment plants, common ores (Ahuja et al., 1999; Kumar et al., 2006; Zinicovscaia et al., 2015). Extra quantity can cause system dysfunctions that outcome in impairment of growth and reproduction. However, Zinc is thought to be generally non-dangerous, particularly if taken orally. (INECAR, 2000; Nolan, 2003). The clinical indications of zinc toxicosis are spewing, bloody urine, diarrhea, icterus (yellow mucus membrane), kidney failure, liver failure and iron deficiency. World Health Organization (WHO) prescribed the greatest allowable concentration of zinc in drinking water as $5.0 \mathrm{mg} / \mathrm{L}$ (Kumar et al. 2006).

\section{Copper (Cu)}

Copper is a metallic element occurs naturally in soil at a usual concentration of about 50 ppm (parts per million). Copper exists in all animals and plants and for humans and animals it is a vital nutrient in small amounts. The smelting, mining and refining of copper, industries manufacturing products from copper for example wire, pipes and metal sheet, and burning of fossil fuels are the main reasons of environmental copper release (Mahurpawar, 2015). Water pipes are regularly made of copper and bath fittings might be produced using brass and bronze compounds that contain copper. Leaching of copper from pipes and bath fittings because of acidic water is the major foundation of copper in drinking water. Blue-green stains left in shower installations indicate the existence of copper in water. Different reliefs of copper to the environment incorporate agricultural use against plant ailments and medicines connected to water bodies to dispose of green growth (Mahurpawar, 2015). As a constituent of metallo enzymes, it is a vital component in mammalian nourishment. In metallo enzymes it performs as an electron donor or acceptor. On the other hand, introduction to abnormal amounts of $\mathrm{Cu}$ can result in various unfavorable wellbeing impacts. The utilization of sustenance and drinking water is the main reason of introduction of people to $\mathrm{Cu}$. incidental ingestion is connected with Serve Cu poisonousness; though, some members of the population might be more defenseless to the unfavorable impacts of high $\mathrm{Cu}$ intake because of hereditary inclination or infection (Stern et al., 2007). Inordinate human consumption of Cu may prompts serious mucosal disturbance and corrosion, extensive capillary destruction, hepatic and renal injury and central sensory system aggravation tracked by depression.
Extreme gastrointestinal aggravation and conceivable necrotic changes in the liver and kidney can likewise happen. The impacts of $\mathrm{Ni}$ exposure change from skin aggravation to harm to the lungs, sensory system, and mucous membranes (Argun et al., 2007).

\section{SOURCES OF HEAVY METALS}

Soil, surface water, and groundwater may emerge as infected with risky compounds resulting from human activities (e.g., enterprise, agriculture, wastewater treatment, production and mining) as well as natural activities (e.g., soil erosion and saline seeps). Pollutants can be traced to a selected source, factor source, or result from massive vicinity, nonpoint source. Contaminants are both inorganic and natural compounds (heavy metals, nitrate, phosphate, inorganic acids, radionuclides and natural chemicals) from sources which include waste substances, explosives, pesticides, fertilizers, prescribed drugs, acidic deposition, and radioactive fallout (Sparks, 1995). The two predominant resources of heavy metals in wastewater are natural and anthropogenic. The natural elements include city run offs, volcanic activities, soil erosion and aerosols particulate at the same time as the anthropogenic sources include steel finishing and electroplating tactics, mining extraction operations, textile industries and nuclear power (Akpor et al., 2014). Then foremost usual sources of heavy metal pollutants in wastewater effluents are soil erosion, volcanic activities, aerosol particles and city run offs. it is suggested that volcanic eruptions produce dangerous affects to the surroundings, climate and health of uncovered individuals. other than the deterioration of social and chemical situations and the gases (carbon dioxide, sulphur dioxide, carbon monoxide, hydrogen sulphide) released all through eruptions, diverse natural compounds and heavy metals, consisting of mercury, lead and gold also are launched (Akpor et al., 2014). The activities from volcanoes are mentioned to be answerable for the discharge of metals which includes arsenic, mercury, aluminum, rubidium, lead, magnesium, copper, zinc and a number of others (Amaral et al., 2006). In addition, a few aerosol (high-quality colloidal debris or water droplet within the air, in a few cases they may be gas) particles may additionally deliver one of a kind forms of contaminant; like cloud, smoke and heavy metals. These heavy metal containing aerosols commonly acquire on leaf surfaces in the form of excellent particulates and can input the leaves thru stomata (Sardar et al., 2013). Certain of the human resources of heavy metals in wastewater effluents are metal finishing and electroplating, mining and extraction processes, textiles activities and nuclear activity. Metal finishing and electroplating involve the deposition of skinny protecting layers into prepared surfaces of metal the use of electrochemical methods. Whilst this takes place, toxic metals can be launched into wastewater effluents. This can be both through rinsing of the product or spillage and dumping of method baths. It is also indicated that the cleaning of process tanks and cleaning of wastewater can generate extensive portions of soggy sludge containing high amount of poisonous metals (Cushnie, 1985). In addition, mining processes can launch poisonous metals to the environment. Metal mining and 
smelting activities are seemed as important resources of heavy metals in surroundings. In environments in which those activities take vicinity, it's miles indicated that massive amount of toxic metals deposits are found in their water, plants, soils and vegetable (Wei et al., 2008).

\section{IMPACTS OF HEAVY METALS}

\section{Impact on soil environment}

Heavy metal pollution affects adversely numerous parameters related to plant quality and production together with variety in composition, size and activity of the microbial community (Yao et al., 2003). Because of this, heavy metals are said to be the important source of the soil pollution. The contamination of soil is generally brought out by the numerous metals like $\mathrm{Cu}, \mathrm{Cd}, \mathrm{Ni}$, $\mathrm{Zn}, \mathrm{Cr}$ (Hinojosa et al., 2004). Various enzymatic activities of the soil get affected indirectly by the heavy metals as they are responsible for the shifting of the microbial community which synthesizes enzymes (Huang et al., 2009). Heavy metals leave the poisonous effects on soil biota by altering key microbial activities and decline in the number and activity of soil microbes. It is very valuable to monitor the functioning of soil microbes in ecosystems having long term contamination by heavy metals (Wang et al., 2007).

\section{Impact on plants}

Heavy metals like $\mathrm{As}, \mathrm{Cd}, \mathrm{Hg}, \mathrm{Pb}$ and Se are not compulsory for growth of the plants as they do not engaged in any known physiological activity in plants. Other i.e. $\mathrm{Co}, \mathrm{Cu}, \mathrm{Mn}, \mathrm{Fe}, \mathrm{Mo}, \mathrm{Ni}$ and $\mathrm{Zn}$ are essential elements for the plants for their growth and metabolism, but when their concentration reaches more than optimal values, these elements can lead to poisoning (Garrido, 2005; Rascio, 2011). Heavy metals uptake by plants and consequent accumulation along the food chain is a latent risk to animal and human health (Sprynskyy et al., 2007). One of the main routes of entrance of heavy metals in the food chain is absorption by plant roots (Jordao et al., 2006). Different plant species and efficiency of different plants in absorbing metals is responsible for the heavy metal accumulation and is evaluated by either soil to plant transfer factors or plant uptake of the metals (Khan et al., 2008). Heavy metals are poisonous in nature for plants and phytotoxiciy of heavy metals for plants is responsible for chlorosis, weak plant growth, yield declination and may be even go together with by cheap nutrient uptake, disorders in plant metabolism and decreased ability to fixate nitrogen in leguminous plants (Guala et al., 2010).

\section{Impact on aquatic environment}

Ecological balance of the aquatic environment can tremendously get affected by the contamination of a river with heavy metals, and the variety of aquatic animals may become limited with the extent of contamination (Ay et al., 2009). Heavy metals reached to aquatic environment are normally tied up in particulate matter which ultimately settle down and become assimilated in sediments (Singh and Kalamdhad, 2011). Therefore, surface deposit is very important sink of metals and other pollutants in aquatic systems. These sediment-bound pollutants can be absorbed by rooted aquatic macrophytes and other aquatic life (Peng et al., 2008). The accumulation of heavy metals by an aquatic organism can be moved through the higher classes of the food chain. Carnivores include humans which are present at top of the food chain, attain utmost of their heavy metal burden from the aquatic environment by way of their nutrition, especially where fish are present so there exist the potential for considerable biomagnifications (Ay et al., 2009). One of the most important pollutant for both marine organisms and humans is mercury $(\mathrm{Hg})$ because its effects on marine organisms and potential hazards to humans. A form of mercury which is formed in aquatic sediments by bacterial methylation of organic mercury is Methyl mercury, which is toxic compound of mercury, actually, all the mercury in fish muscles found as methyl mercury (Soliman, 2006). Salmonid species depend upon driftprone macro invertebrates commercially or recreationally, so it is very important to assess the effects of heavy metal contamination on drift-prone macro invertebrates (Iwasaki et al., 2009).

\section{Impact on humans}

By exposure heavy metal pollution can affect the population in many ways causing disorders like insomnia, depression, irritability, fatigue, decreased concentration, gastric symptoms, sensory symptoms (Hanninen and Lindstrom, 1979). The use of heavy metal contaminated food crops is an important food chain path for exposure of humans to heavy metals (Singh and Kalamdhad, 2011). The farming of such plants which have a great ability of removing elements form soils reflects a possible threat as the plant tissue can accumulate heavy metals (Jordao et al., 2006). When metabolization of the heavy metals is not done by the body and they get accumulate in the soft tissues, they become toxic (Sobha et al., 2007). It is reported that the heavy metals are responsible for encouraging tumor and mutations at larger extents in animals (Degraeve, 1981). Heavy metals have the capacity of creating genetic damage to germ cells animals. (Hayes, 1984; Groten and Vanbladeren, 1994; Wagner, 1993). Heavy metals are tremendously toxic in living beings even in smaller amount. Consumption of food or water drinking with very greater grade of heavy metals persistently inflames the stomach which results as diarrhea and vomiting. Similarly, more amount of Lead $(\mathrm{Pb})$ may be responsible for reducing response time, and outcome in anemia, a disease of blood in humans (ATSDR, 1993). Contaminated food by heavy metals can harshly decrease some vital nutrients in the body which decrease immunological defenses, reduced psychosocial abilities, growth delay, incapacities related with malnutrition and larger incidence of upper gastrointestinal cancer degrees (lyengar and Nair, 2000; Türkdogan et al., 2003; Arora et al., 2008). Cadmium, Copper, Lead, Nickel and Zinc are the heavy metals which can result in deadly health complications in humans when contact is long termed (Reilly, 1991). These heavy metals have lengthy biotic half-lives and also these can store in many organs of the body and so results in irritating side effects (Jarup, 2003; Sathawara et al., 2004; Ata et al., 2009). 


\section{PHYTOREMEDIATION PROCESSES}

The diverse activities of plants and their related rhizosphere bacteria on pollutants comprise phytoextraction, phytostabilization, phytodegradation, rhizodegradation, rhizofiltration and phytovolatilization (Salt et al., 1995; USEPA, 2001).

\section{Phytofiltration or rhizofiltration}

It is defined as the use of plants either terrestrial or aquatic; to absorb, concentrate, and precipitate pollutants from polluted aqueous sources with low contaminant concentration in their roots. Partially detoxification of industrial release, agronomic runoff, or acid mine drainage can be achieved by rhizofiltration. Rhizofiltration may be applicable for lead, cadmium, copper, nickel, zinc and chromium, which are chiefly engaged with in the roots (Chaudhry et al., 1998; USPA, 2000). There are various benefits of rhizofiltraion like it can be used as in-situ or ex-situ applications and numerous species are also applicable other than hyperaccumulators. Plants like sunflower, Indian mustard, rye, tobacco spinach and corn have been tested for their capability to eliminate lead from effluent, with sunflower having the highest ability. It is proved by the tests that Indian mustard has ability to remove a varied concentration range of lead (4-500 $\mathrm{mg} / \mathrm{l}$ ) (Raskin and Ensley, 2000). A number of species of Sargassum biomass (nonliving brown algae) was found to be an effective biosorbent for heavy metals, like $\mathrm{Cu}$ and $\mathrm{Cd}$ (Davis et al., 2000). Tomato and tobacco roots gathered from field-grown plants were found greatly effective bioadsorbents that could adsorb strontium (Sr) from an aqueous solution of $\mathrm{SrCl}_{2}$. Tang and Willey (2003) examined the plant uptake of ${ }^{134} \mathrm{Cs}$. Plants from the Asteraceae family accumulated great concentrations of radiocesium than Beta vulgaris and provided a new applicant for phytoremediation of radiocesium-polluted soils. Zurayk et al. (2001) assessed the role of wetland plants (Nasturtium officinale, Mentha longifolia, Veronica beccabunga, and Cardamine uliginosa) in aquatic phytoremediation of $\mathrm{Cr}$ and the result was that $\mathrm{Cr}$ was chiefly stored in roots with slight shoot translocation. Accumulation had gotten $6700 \mathrm{mg} \mathrm{Cr} \mathrm{kg}{ }^{-1}$ in roots of $\mathrm{V}$. beccabunga.

\section{Phytostabilisation}

Phytostabilisation is typically applicable in decontamination of soil, residue and sludges (USPA, 2000; Mueller et al., 1999) and depends on roots skill to limit pollutant movement and bioavalability in the soil. It can happen through the sorption, precipitation, complex action, or metal valence decline. Reducing the quantity of water percolating by the soil matrix is the chief resolution of plants which may form dangerous leachate and prevent soil erosion and distribution of the noxious metal to other areas. A compact root system stabilizes the soil and avoids erosion (Berti and Cunningham, 2000). Phytostabilisation does not remove the pollutant from the soil, but it reduces the characteristic hazard of the pollutant ( $\mathrm{Li}$ et al., 2000). It is valuable for the decontamination of lead $(\mathrm{Pb})$ chiefly along with arsenic (As), chromium (Cr), cadmium (Cd), copper (Cu) and zinc (Zn). The disposal of dangerous material/biomass is not required
(USPA, 2000) and it is very useful when quick immobilization is desired to preserve ground and surface waters are some of the benefits linked with this technology. Reduction of soil erosion and declination the amount of water available in the system is also due to the presence of Plants (USPA, 2000). Polluted land areas affected by mining activities and Superfund sites have been treated by phytostabilization. Jadia and Fulekar (2008) conducted the experiment on phytostabilization in a greenhouse, using sorghum to remediate heavy metal polluted soil and the vermicompost generated by the experiment was used in contaminated soil as a natural fertilizer. The study reviled that at the higher concentration of 40 and 50 ppm the growth was unfavorably affected by heavy metals, on the other hand, the lower concentrations (5 to $20 \mathrm{ppm}$ ) inspired enhanced plant biomass and shoot growth. Reduced leaching by stabilization of soil and immobilizing and concentrating heavy metals into the roots was done by the large surface area of fibrous roots of sorghum and intensive penetration of roots into the soil.

\section{Phytoextraction}

Phytoextraction is the finest method to eliminate the contamination primarily from soil and separate it, without harming the soil arrangement and productiveness. It is also called phytoaccumulation (USPA, 2000). As the plant absorb, concentrate and precipitate toxic metals and radionuclide from contaminated soils into the biomass, it is appropriate for the remediation of diffusely contaminated areas, where noxious waste occur solely at comparatively low concentration and superficially (Rulkens et al., 1998). Numerous methodologies have been used but the two simple strategies of phytoextraction, which have lastly developed are; i) Chelate assisted phytoextraction or induced phytoextraction, in which non-natural chelates are added to rise the movement and uptake of metal pollutant. ii) Nonstop phytoextraction, in this the elimination of metal depends on the natural capacity of the plant to remediate; only the number of plant growth repetitions are controlled (Salt et al., 1995, 1997). Most plants do not accumulate metals to noteworthy levels in aboveground biomass, while metal-tolerant plants are comparatively common. However, some plant species are skilled of hyper accumulation of metal ions as they are capable to take up and accumulate metals at concentrations of higher than 0.1 percent (by dry weight of plant) or greater (Brooks, 1998). Hyperaccumulators have been used as applicants for phytoextraction due to their capability to uptake metals and translocate those metals from soil into harvested above-ground biomass (Kumar et al., 1995). A range of terrestrial plant species have been recognized as having the capability to hyper accumulate certain metals from soil including Brassica, Aeollanthus, Thlaspi, Apocynum and Paspalum among others (Baker, 1995; Kramer et al., 1996).

\section{Phytovolatilization}

Phytovolatilization is the process in which plants take up pollutants from the soil, convert them into volatile form and transpire them into the atmosphere. Phytovolatilization take place as growing trees and other plants absorb water and the 
organic and inorganic pollutants. Some of these pollutants can pass through the plants to the leaves and volatilize into the atmosphere at relatively low concentrations (Mueller et al., 1999). Phytovolatilization has been mainly used for the removal of mercury; the mercuric ion is converted into less noxious elemental mercury. The drawback is mercury released into the atmosphere is expected to be recycled by precipitation and then redeposit back into bionetwork (Henry, 2000). Phytovolatilization of selenium can be done by Indian mustard and canola (Brassica napus) and have been reported that it accumulate the selenium (Bañuelos et al., 1997).

\section{Phytodegradation}

One of the most significant phases in the procedure of remediation of organic pollutants is degradation of the pollutant. Degradation of a compound denotes to its breakdown into smaller constituents, or its conversion to a metabolite (Arthur et al., 2005). Plants have enzymes which can breakdown and transform ammunition wastes, chlorinated solvents like trichloroethylene and other herbicides. The enzymes are typically dehalogenases, reductases and oxygenases (Black, 1995). In a phytoremediation, degradation can occur in the rhizosphere (soil surrounding plant roots), as well as inside the plant itself. The latter, phytodegradation, occurs when a plant absorb the contaminant into the tissues, and enzymes within the plant got engaged into converting the compound, frequently into molecules that can be more readily cracked down or released in root exudates. Enzymes exuded from microorganisms or plants are applicable in rhizodegradation or transformation of the pollutant in the rhizosphere, in soil organisms such as bacteria and fungi (for example, Schultz et al., 2001; Siciliano et al., 1998). Moreover, degradation of organics done by the microorganisms can be supported by plants, by the nutrient potential of plant root exudates (Kumar et al., 2019b).

\section{Phytoremediation studies}

Various plant species which can accumulate the heavy metals has been comprehensively studied and to date substantial growth has been made in the area of hyper accumulation of heavy metals by plants. Different plant species has different mechanisms of metal accumulation, exclusion and compartmentation (Lone et al., 2008). Elimination of contaminants from the polluted waters by accumulation into plant biomass is termed as Rhizofiltration. Hyperaccumulators can be utilized for phytoremediation of lethal and dangerous overwhelming metals and in addition for phytomining of valuable substantial metals, (for example, $\mathrm{Au}, \mathrm{Pd}$ and $\mathrm{Pt}$ ). The utilization of hyper-accumulators for phytoremediation may result in the production of a bio-mineral of some business incentive to adapt to a portion of the expenses of soil remediation (Brooks et al., 1998). For specific heavy metals some plants have natural capability of hyper accumulation. These plants of having such a capacity are known as natural hyperaccumulators. Then again, the accumulation capacity of a few plants for particular heavy metals can be improved by their genetic change through biotechnological techniques. Such genetically altered plants have indicated promising outcomes for phytoremediation of some heavy metals. In any case, since some environmental researchers are doubter about the bio-safety of genetically modified organisms (GMOs), subsequently there is an overall worry about the commercialization of such items (Prakash et al., 2011).

Phytoremediation of heavy metals from the contaminated water by numerous aquatic species have been acknowledged and tested. Some of the hyperacuumulators are duck weed (Lemna minor L.), water hyacinth (Eichhornia crassipes), sharp dock (Polygonum amphibium L.), water dropwort [Oenathe javanica (BL) DC], calamus (Lepironia articulate), pennywort (Hydrocotyle umbellate L.) water lettuce (P. stratiotes), (Vara and Freitas, 2003). Removal of $\mathrm{Cd}, \mathrm{Ni}, \mathrm{Pb}, \mathrm{Cr}, \mathrm{Cu}$ and $\mathrm{Zn}$ by the roots of Indian mustard is found to be effective and sunflower can eliminate $\mathrm{Pb}, \mathrm{Cs}-137, \mathrm{U}$, and $\mathrm{Sr}-90$ from the solutions which are hydroponic (Zaranyika and Ndapwadza, 1995; Wang et al., 2002; Vara and Freitas, 2003). The efficiency of duck weed was examined by Zayed et al. (1998) for the removal of $\mathrm{Cd}, \mathrm{Ni}, \mathrm{Cr}$, $\mathrm{Cu}, \mathrm{Pb}$ and $\mathrm{Se}$ from the solution which was nutrient-added. It was found that duck weed is a decent accumulator for $\mathrm{Cd}$, Se and $\mathrm{Cu}$, but accumulate $\mathrm{Cr}$ moderately and poorly accumulate $\mathrm{Ni}$ and $\mathrm{Pb}$.

Water hyacinth (Eichhornia crassipes) claims a well-built stringy root framework and substantial biomass and has been effectively utilized in wastewater treatment frameworks to enhance water quality by diminishing the levels of natural and inorganic nutrients. Eichhornia crassipes was found to be effective in the elimination of $\mathrm{Pb}$ from industrial effluents in a green-house study (Santos and Lenzi, 2000). This plant can likewise decrease the concentrations of heavy metals in corrosive mine water while showing few indications of poisonous quality. Water hyacinth amasses follow components, for example, $\mathrm{Ag}, \mathrm{Pb}, \mathrm{Cd}$, etc., and is beneficial for phytoremediation of wastewater contaminated with Cd, Cr, Cu and Se (Zhu et al., 1999).

Five wetland plant species, i.e., sharp dock, duckweed, water hyacinth, water dropwort and calamus was investigated by Wang et al. (2002) with the help of pot experiment for their conceivable use in improving the contaminated waters. The results revealed that sharp dock was a decent accumulator of $\mathrm{N}$ and $\mathrm{P}$ Duckweed and Water hyacinth largely accumulated $\mathrm{Cd}$ with a concentration of 14200 and $462 \mathrm{mg} / \mathrm{kg}$, respectively. Water dropwort accumulated the highest concentration of $\mathrm{Hg}$, whereas the calamus attained $\mathrm{Pb}(512 \mathrm{~m} / \mathrm{kg})$ considerably in its roots. Hydroponic examinations to explore the uptake of $\mathrm{As}, \mathrm{Cr}$, $\mathrm{Hg}, \mathrm{Ni}, \mathrm{Pb}$ and $\mathrm{Zn}$ by water hyacinth from the aqueous solution at the concentrations extending from 5 to $50 \mathrm{mg} / \mathrm{L}$ was conducted by Ingole and Bhole (2003) and found that in aqueous solutions containing $5 \mathrm{mg} / \mathrm{L}$ of $\mathrm{As}, \mathrm{Cr}$ and $\mathrm{Hg}$, the most extreme uptake was 26, 108 and $327 \mathrm{mg} / \mathrm{kg}$ dry weight of water hyacinth, respectively. Pteris vitta commonly known as Brake fern among the ferns is well recognized for hyperacccumulation of As from polluted soils and waters. It can collect up to $7500 \mathrm{mg}$ As/kg on a polluted site (Ma et al., 2001) without indicating poisonous quality side effects. 


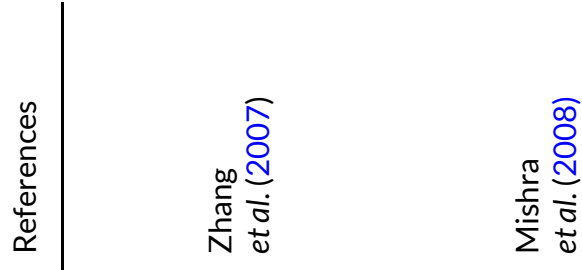<smiles>[C-]#[C-]</smiles>

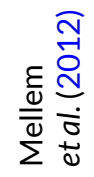

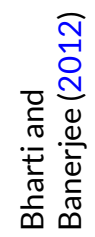

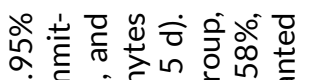

○े एं

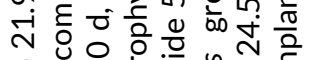

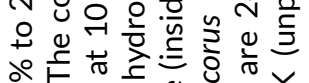

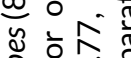

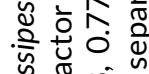

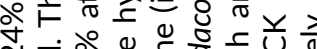

काँ

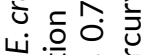

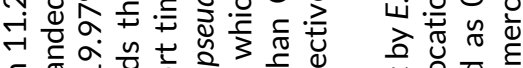

ह त

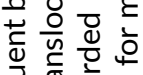

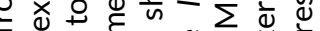

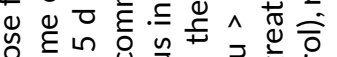

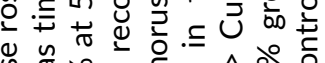

乐它

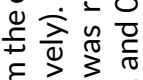

\%ั

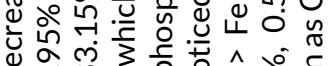

일

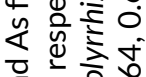

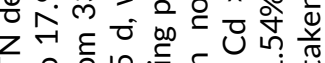

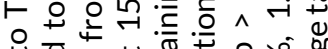

प ष्ठ

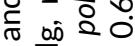

an I vi

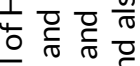

元罂高.

ฮิ

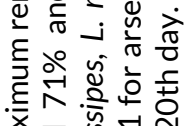

这离论

ㅇํㅇ ㅇำ

ㅇํㄴ 孛

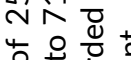

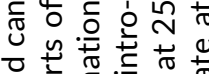

己

它. 岂.

융

응 웠 엉

जै ते

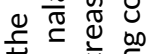

$\subseteq \frac{\pi}{00} \frac{\bar{d}}{0} \cdot \frac{\subseteq}{\overline{0}}$

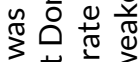

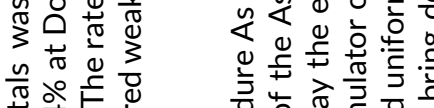

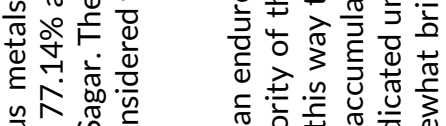

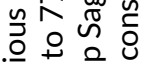

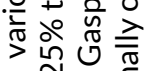

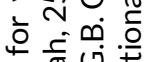

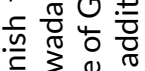

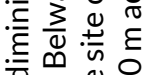

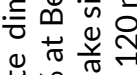

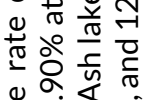

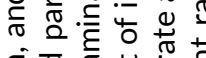

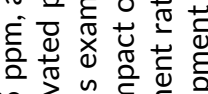

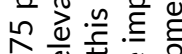

पे

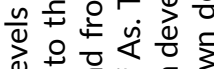

ब)

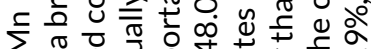

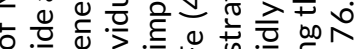

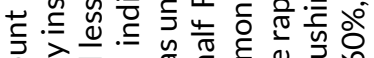

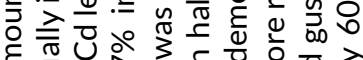

宁 行

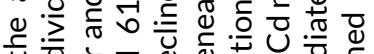

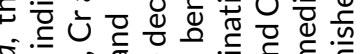

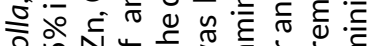

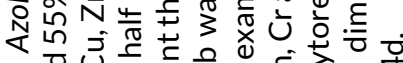

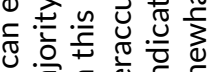

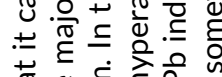

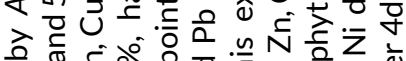

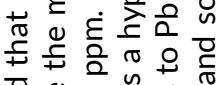

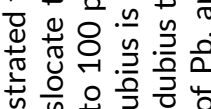

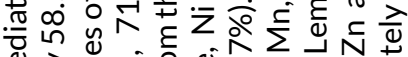

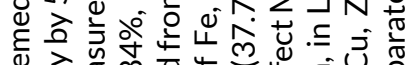

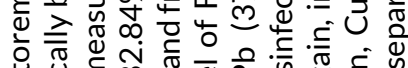

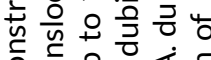

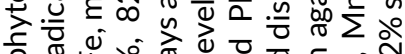

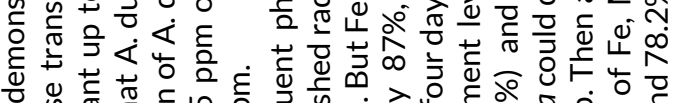

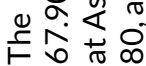

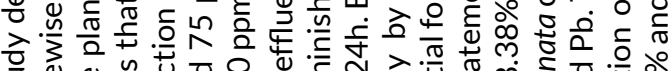

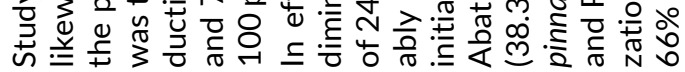

$\hat{z-\frac{a}{E}}$

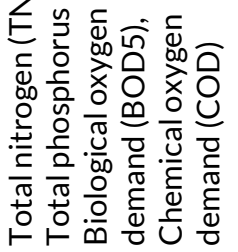

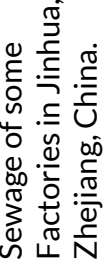

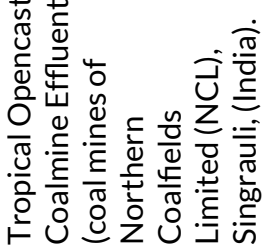

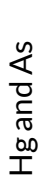

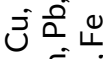

บें
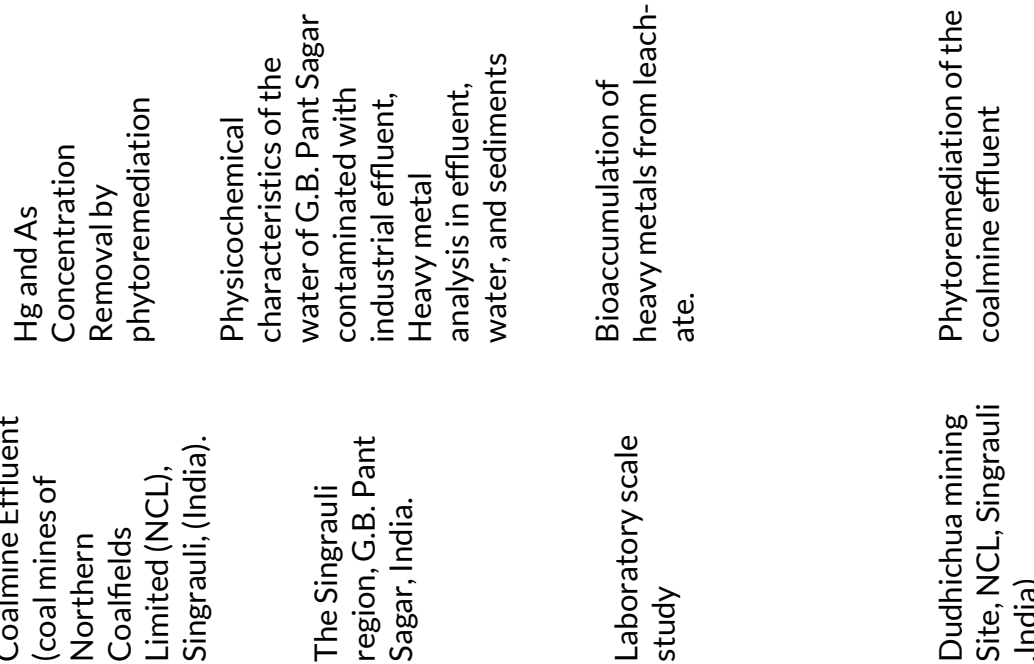

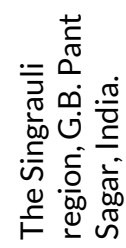

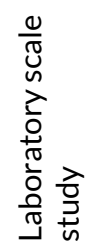

กี $\frac{\bar{C}}{\sigma}$

$\sum \frac{100}{1}$

نิ

บั จำ

s̊

过.

모듬

ษ๋

起定

J゙்

ปัป

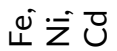
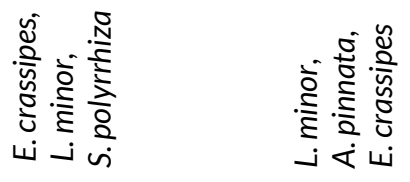

$\frac{n}{3}$
$\frac{3}{3}$
$\frac{3}{0}$

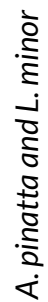




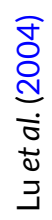

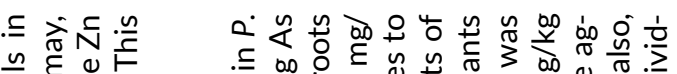

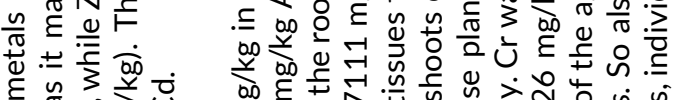
E

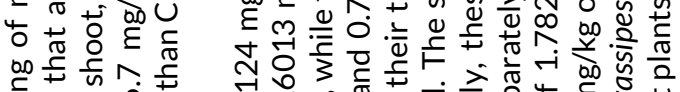
흥 용 웡 के

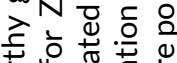

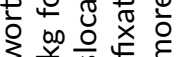

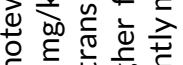
돈

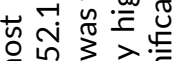

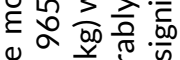

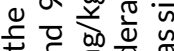
त $\frac{\pi}{\pi} \frac{\pi}{\omega}$

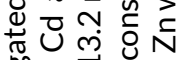

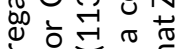

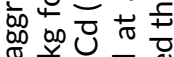

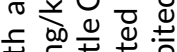

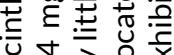
突过

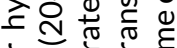

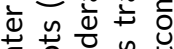

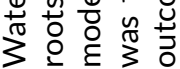

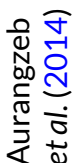

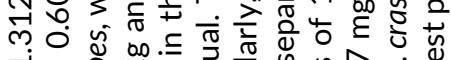

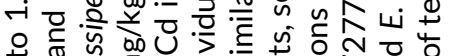

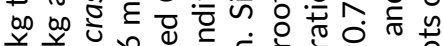

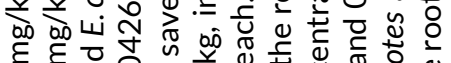
๙ m. o.

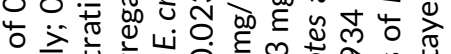

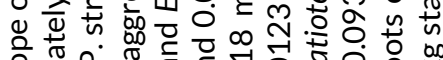

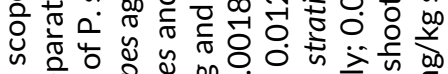

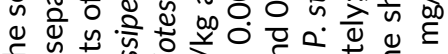

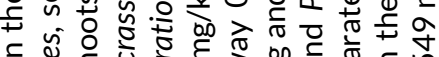

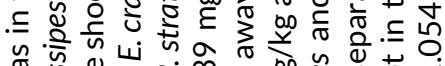

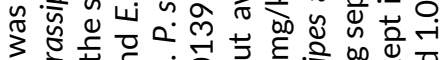

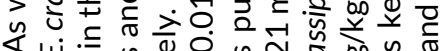
ष山 ن

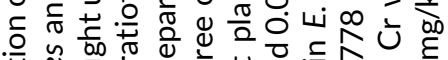

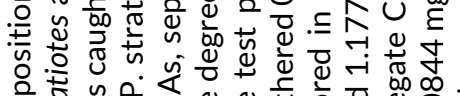

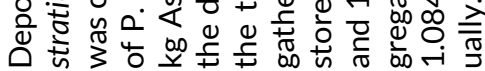
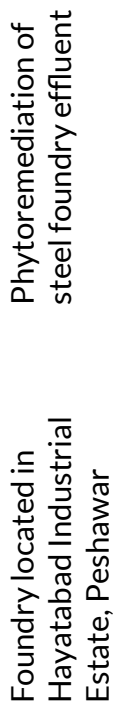

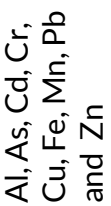

产离

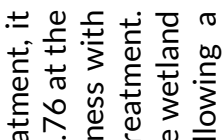

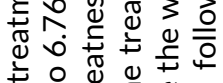

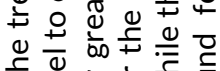

的市地

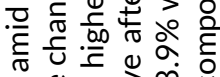

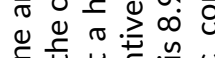

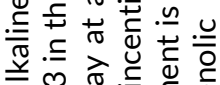

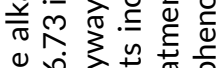

ㄴํㅇ

ह $\varepsilon$ o

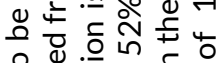

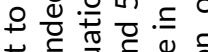

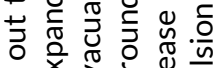

过选过市选

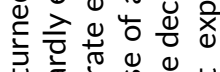

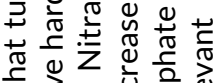

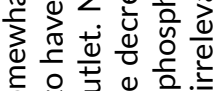

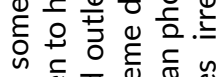

I

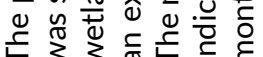

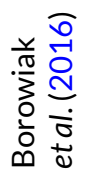

象

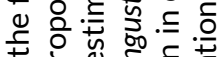

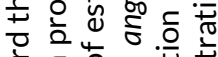

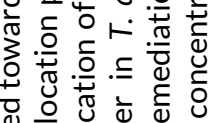

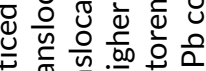

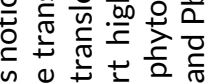

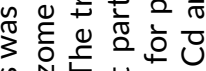

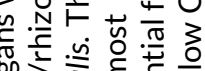
o.

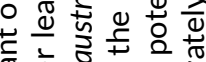
元造这就

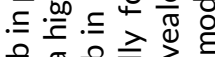

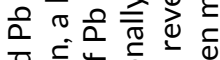

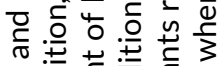

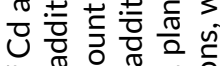
능 $\stackrel{0}{0}$ 은

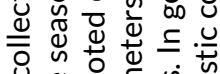
O

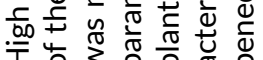

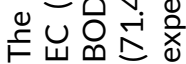
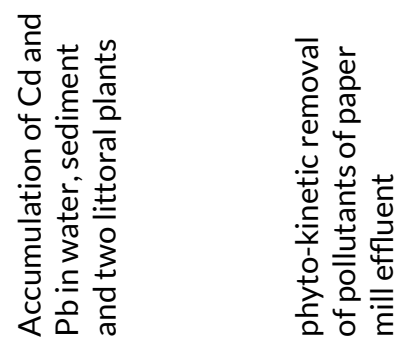

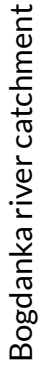

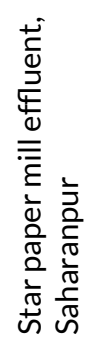

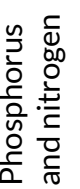

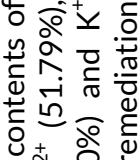
讨穴 어응 능

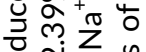

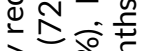
ते वें वे

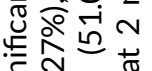
.0.0.0.

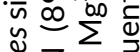

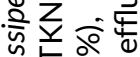
它 $\div$ 山 ㅇํㅇ

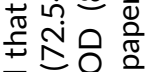
एँบ 员 ज०० \pm ले
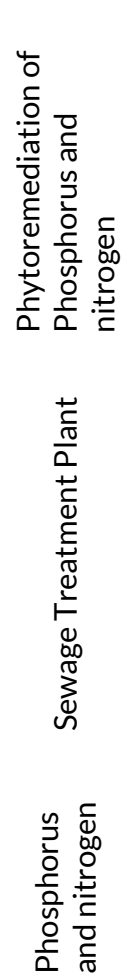

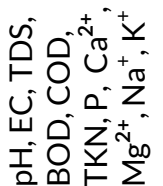


Vinod Kumar and Piyush Kumar /Arch. Agr. Environ. Sci., 4(3): 326-341

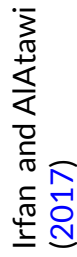

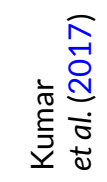

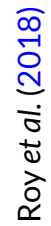

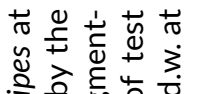

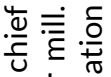

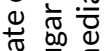

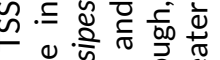

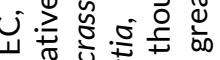

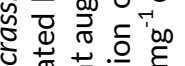

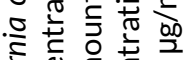

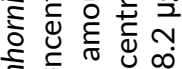

它

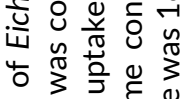

उ.

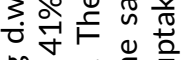

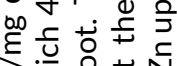

을

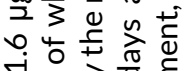

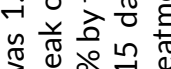

उँ Оे ने बं

N过艺这

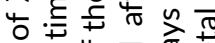

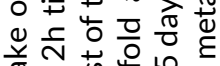

.

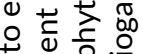

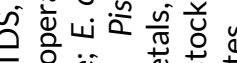

준

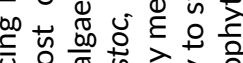

ज证定

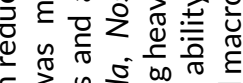

ए

는 윈

吃 它

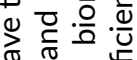

西

웅

ว

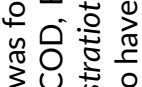

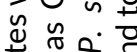

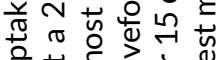

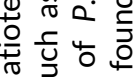

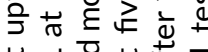

苟 $\frac{1}{0}$ 它

竎出

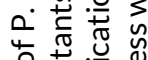

$\leqq 30 \frac{5}{8} .00$

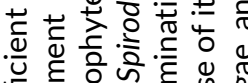

重

造 范宅.

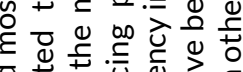

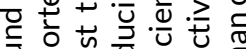

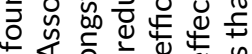

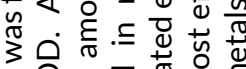

उ०

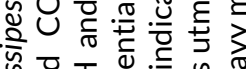

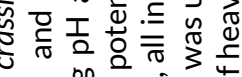

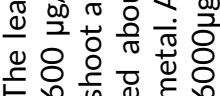

岁言容遂

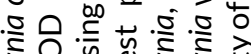

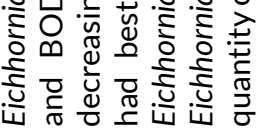

\& छ

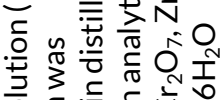

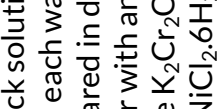

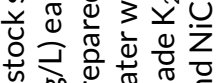

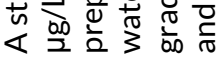

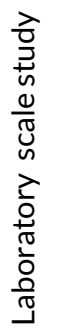
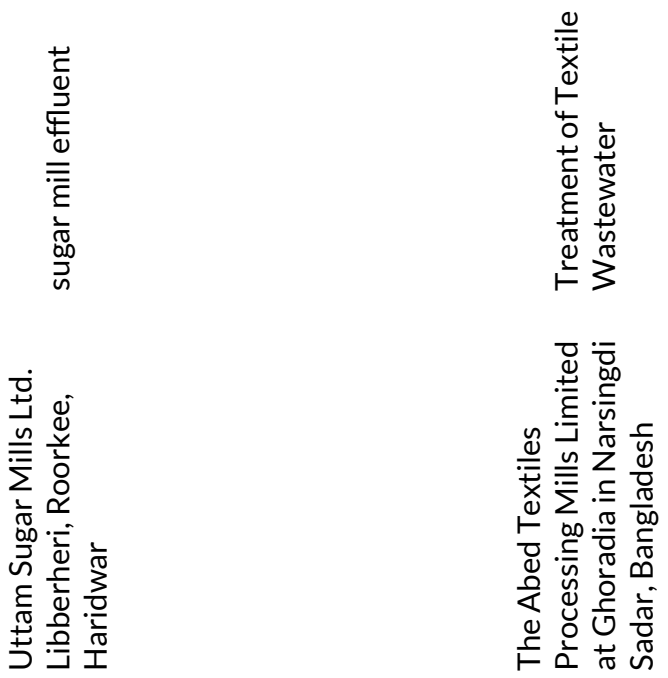

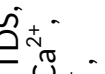

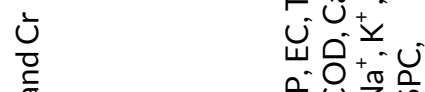

ดी

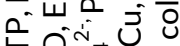

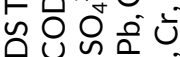

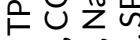

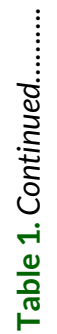

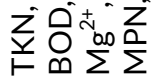

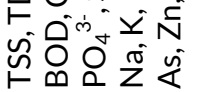
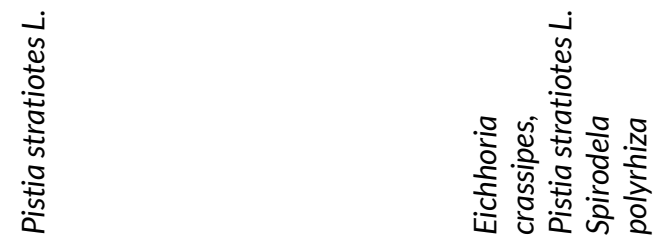
Rai (2008) conducted an experiment to encounter phytoremediation of $\mathrm{Hg}$ and $\mathrm{Cd}$ from industrial effluents using $\mathrm{A}$. pinnata, an aquatic free floating macrophyte. The conclusion of the experiment was that the A. pinnata has a tremendous potential of phytoremediation. Azolla pinnata accumulated heavy metals, i.e., $\mathrm{Hg}$ and $\mathrm{Cd}$ (70-94\%) and may be utilized as a bioaccumulator to control heavy metals in chlor-alkali effluent and ash slurry. Mishra et al. (2008) investigated tropical opencast coalmine effluent and studied the phytoremediation of heavy metals mercury and arsenic through naturally occurring aquatic macrophytes and concluded that three species of aquatic macrophytes L. minor, E. crassipes and S. polyrrhiza showed extremely operative in eliminating heavy metals from the effluent of coal mining throughout 25 days experimentation. The macrophytes eliminated considerable quantities of the $\mathrm{Hg}$ and As. However, these metals had led their poisonous effects by reducing chlorophyll, protein and Nitrogen, Phosphorus, potassium, content of the experimental macrophytes.

Roots of the macrophytes indicated improved collector of the heavy metals as they always exposed to greater quantity of $\mathrm{Hg}$ and As in contrast to the leaves. Rai and Tripathi (2009) performed a comparative valuation of Azolla pinnata and Vallisneria spiralis in $\mathrm{Hg}$ elimination from G.B. Pant Sagar and concluded that Aquatic plants might be capable applicant for phytoremediation of $\mathrm{Hg}$ from thermal power plant, coalmine and chlor-alkali effluent. The results got suggested that both $A$. pinnata, and $V$. spiralis, a can eliminate $\mathrm{Hg}$ from industrial discharges. A. pinnata taken up $\mathrm{Hg}$ more proficiently than $\mathrm{V}$. spiralis and is thus suggested for elimination of $\mathrm{Hg}$ from polluted waters. Being submerged macrophytes $V$. spiralis may be more valuable to eliminate $\mathrm{Hg}$ from sediments in natural/field sites. Rai (2009) assessed a microcosm examination on phytoremediation of Chromium Using Azolla Pinnata. The study concluded that Azolla pinnata has the wonderful capability to accumulate $\mathrm{Cr}$ (III) and $\mathrm{Cr}(\mathrm{VI})$ (70-88\%) and can be utilized as a bioaccumulator to control heavy metals in, coalmine, ash slurry and tannery effluent. Prasad and Singh (2011) performed an experimentation to find out the metabolic responses of Azolla pinnata to cadmium stress and concluded that Azolla can be utilized for the treatment of heavy metal to confident degree and as a sustainable performance to eliminate the heavy metal from contaminated sites. Baruah et al. (2014) studied the Phytoremediation of Arsenic by Trapa natans in a Hydroponic System and the study concluded that $T$. natans is a decent hyperaccumulator of arsenic in the roots as well in aboveground plant portions. Irrespective of the concentration, the roots were found to be best effective in the taking up of arsenic. While some external symptoms of poisonousness were detected at greater arsenic concentration, the plants were incapable to fight arsenic toxicity because of proline synthesis and amassing. Study concluded that $T$. natans can be suggested for the elimination of arsenic from polluted water. Kooh el al. (2016) used Azolla pinnata for the Separation of poisonous rhodamine $B$ from aqueous solution by adsorption method and reviled that thermodynamics study showed endothermic, spontaneity and physisorption-dominant adsorption process. The adsorbent, while showed a reduction in the first cycle of renewal, was able to afterward uphold up to five cycles of renewal with distilled water, $\mathrm{HNO}_{3}$ and $\mathrm{NaOH}$. Akinbile et al. (2016) conducted an experiment to find out the Phytoremediation of domestic wastewaters in constructed wetlands using Azolla pinnata and concluded that Azolla pinnata had proven to be a very reliable in treating municipal wastewater going by the results obtained. Kumar et al., (2017) inspected the potential of Eichhornia crassipes using the paper mill effluent and found Eichhornia crassipes a very promisive agent for the phytoremediation of paper mill effluent. They reported that the greatest reduction was detected in the EC (62.23\%), COD (85.66\%), TDS (72.54\%), BOD (79.93\%), TKN (89.27\%), $\mathrm{Ca}^{2+}$ (51.79\%), P (72.39\%), $\mathrm{Mg}^{2+}(51.02 \%), \mathrm{Na}^{+}$ (57.10\%) and $\mathrm{K}^{+}(71.47 \%)$. Kumar et al. (2017) did an experimental and kinetics study for phytoremediation of sugar mill effluent using water lettuce (Pistia stratiotes L.) and used its biomass for the production of biogas. The study concluded that $P$. stratiotes achieved remarkable decrease in nutrient (TKN, 72.86\%; TP, 71.49\%) and pollutant load (EC, 25.69\%; BOD, 69.40\%; COD, 61.80\%; TDS, 57.26\%; $\mathrm{Ca}^{2+}, 56.79 \% ; \mathrm{Mg}^{2+}$, $55.01 \%$; Na, 42.86\%; K, 54.38\%; MPN, 78.13\%; SPC, 60.13\%) from $75 \%$ sugar mill effluent at the end of the experimentation (Table 1 and 2).

\section{NECESSITY OF PHYTOREMEDIATION}

There is an urgent need for alternative, cheap and efficient methods to clean up heavily contaminated industrial areas. Phytoremediation, using plants to bio remediate infected soil, water, and air, has emerged as an inexpensive, noninvasive, and publicly acceptable manner to address the elimination of environmental contaminants (Boyajian and Carreira, 1997; Singh et al., 2003). For countries like India, which are still developing, such capabilities of the aquatic macrophytes could be of huge importance where many shallow ponds and marshlands are having unfavorable condition for traditional fish farming and agriculture (Mohan Ram, 1978). Various species show different behavior regarding their efficacy to accumulate elements in roots, stems and/or leaves. Therefore, it will be very useful to find out the better trace element accumulator and its organ that absorbs the highest amount of trace factors (Baldantoni et al., 2004). By the wetland treatment the production of edible biomass of aquatic macrophytes can give back economic returns to harvester. These economic paybacks can be realized by the generation of "bio-gas", animal feed, fiber for paper making, compost etc. (Lakshman, 1987). Phytoremediation of water bodies may be grabbed as an opportunity along with ordinary treatment approaches like ion exchange resins and electrodialysis, microfiltration, chemical precipitation, sedimentation, and reverse osmosis (Rai, 2009). The treatment of the heavy metal contamination by modern machineries is very expensive for many developing countries like India which may not be able to meet the expense of the huge costs required for the treatment (Rai and Tripathi, 2007; Rai, 2008). 


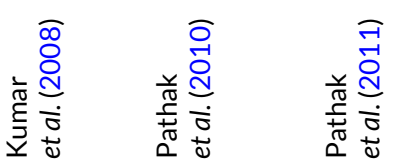

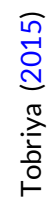<smiles>C1[C@H]2C[C@H]1[C@H]1C[C@@H]2C1</smiles>

离完部

过

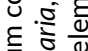

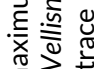

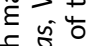

专家这

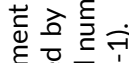

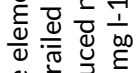

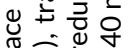

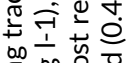

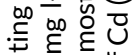

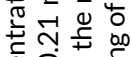

远记

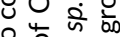

范

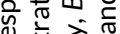

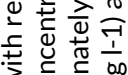

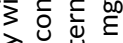

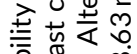

용

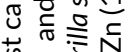

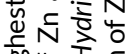

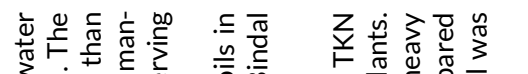

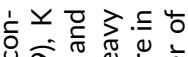

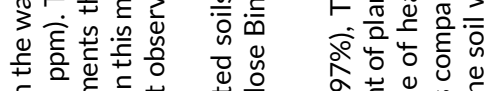

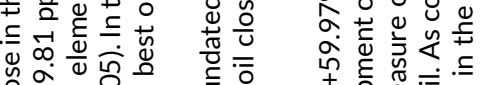

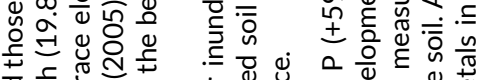

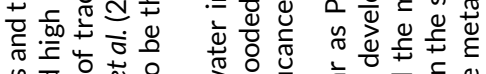

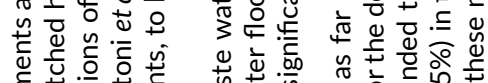

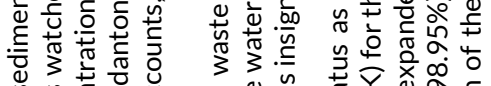

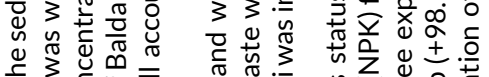

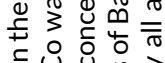

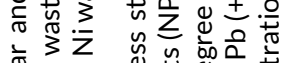

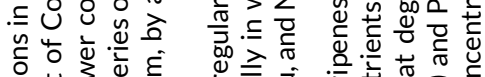

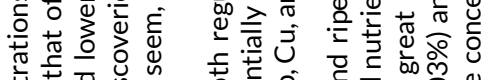

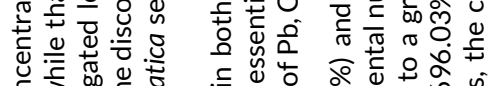

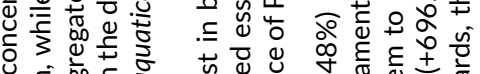

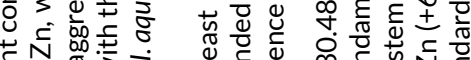

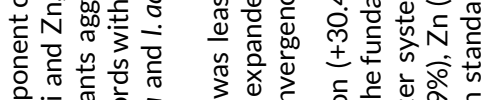

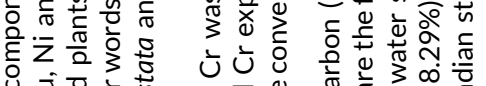

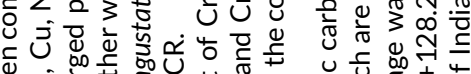

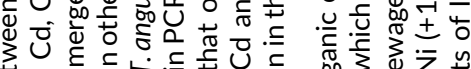

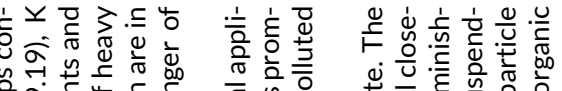

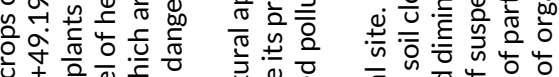

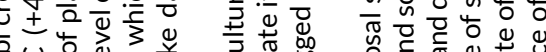

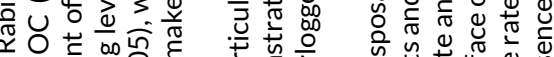

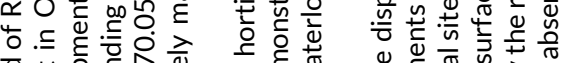

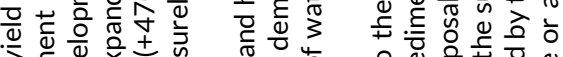

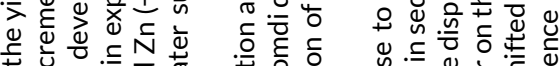

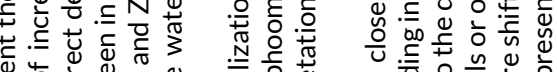

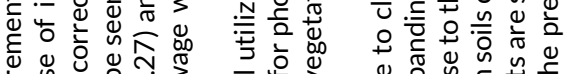

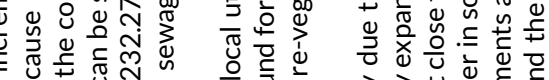

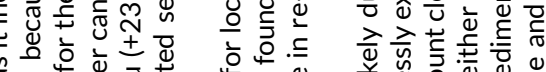

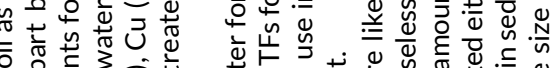

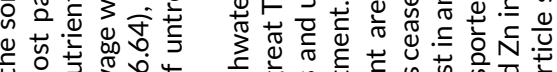

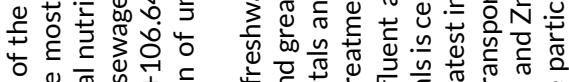

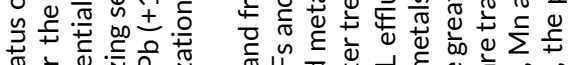

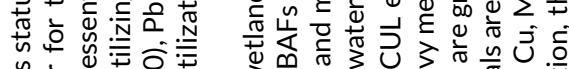

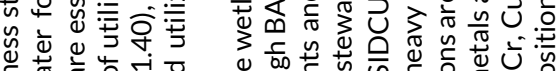

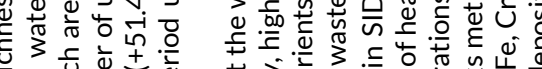

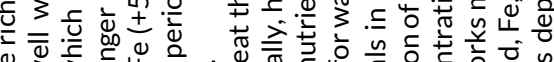

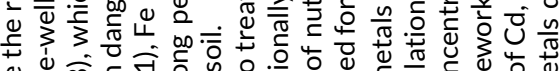

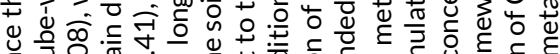

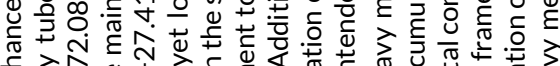

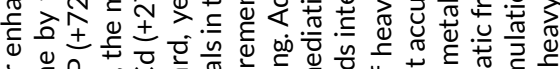

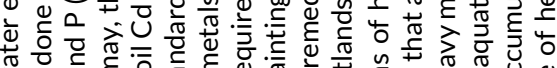

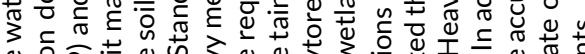

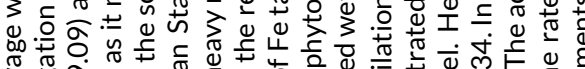

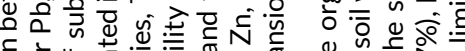

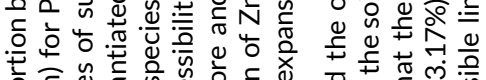

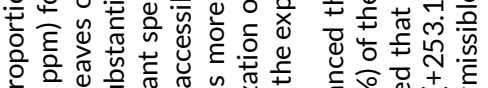

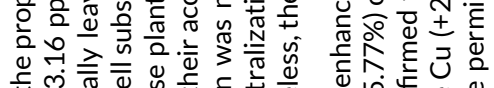

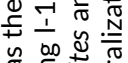

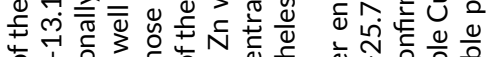

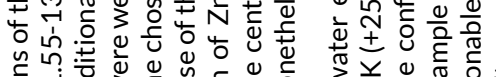
足 कि

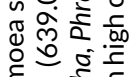

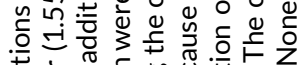

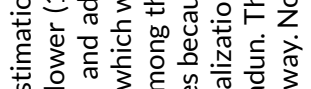

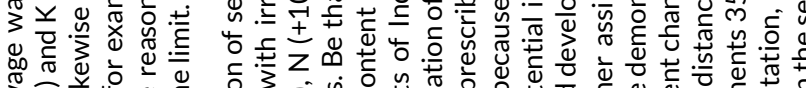
3.000

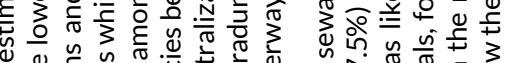

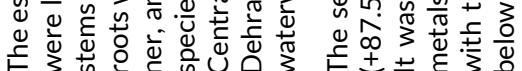

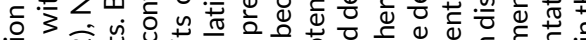

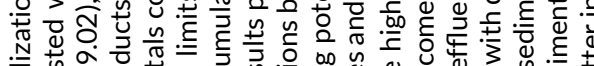

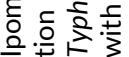

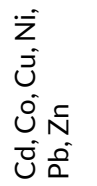

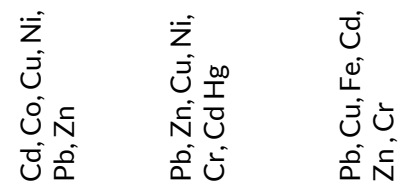

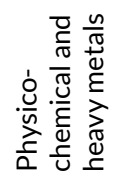
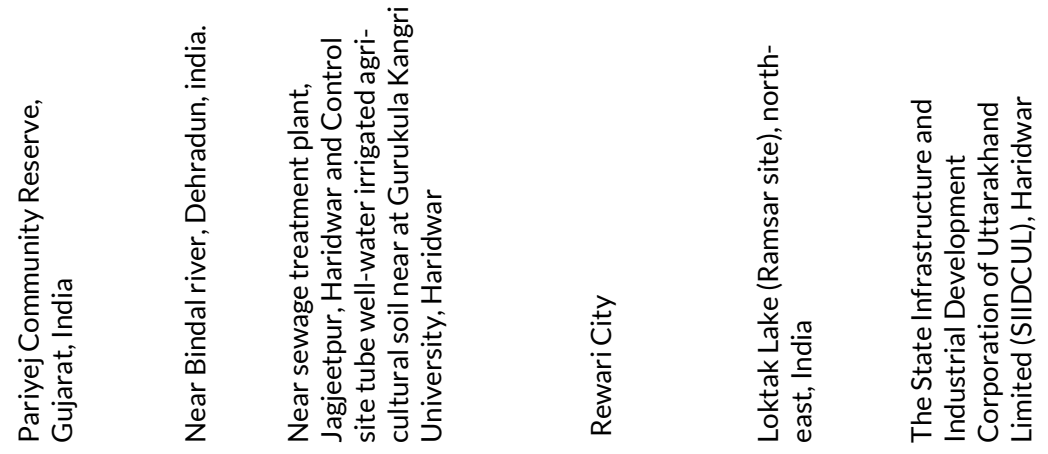

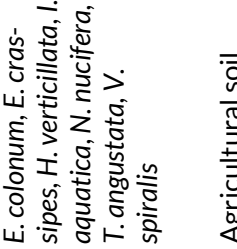
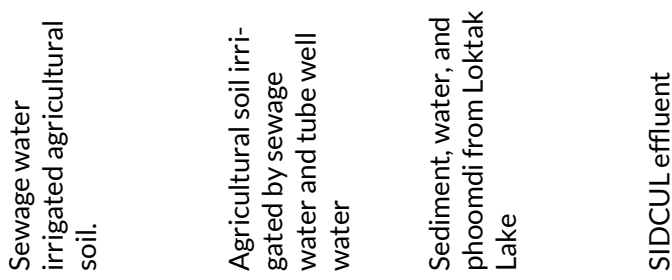


\section{Conclusion and recommendation}

Soil and Water pollution is a serious worldwide concern; to encounter this problem effective remediation methods are needed. Phytoremediation is environmental-friendly, costeffective and solar-driven technique for heavy metal elimination from aquatic environments with decent community acceptance. Aquatic macrophytes are effective tools to eliminate heavy metals from aquatic bodies and have drawn a lot of responsiveness throughout the world. Both live and dead macrophytes work as a tool of bio-filtration for the heavy metals, in both the natural and manmade wetlands. The problem of discarding of biomass and periodic growth of aquatic macrophytes are few of the limits in the assignment of phytoremediation technique from the laboratory to the field of work. Though, an environmental friendly model has been established by the various works that may control some of the limitations. Biomass of macrophytes can be utilized for various productive applications. Industrial discharges and secondary-treated municipal wastewater can be improved with the application of aquatic macrophytes and disposed biomass may be reused for the production of biogas. Biodiversity prospecting, $X$-ray diffraction spectroscopy and Genetic engineering are encouraging future visions concerning the use of aquatic macrophytes in phytoremediation applications. A combined methodology and multidisciplinary approach may enable this developing technology to become the new edge in environmental science and technology.

Open Access: This is an open access article published under the terms and conditions of Creative Commons AttributionNonCommercial 4.0 International License which permits noncommercial use, distribution, and reproduction in any medium, provided the original author(s) if the sources are credited.

\section{REFERENCES}

Agency for Toxic Substances and Disease Registry (1993). Toxicological profile for cadmium atlanta. US Deptartment of Health and Human Services, Public Health Service.

Ahuja, P., Gupta, R. and Saxena, R.K. (1999). $\mathrm{Zn}^{2+} \mathrm{C}$ biosorption by Oscillatoria anguistissima. Process Biochemistry, 34(1): 77-85, https://doi.org/10.1016/S0032-9592(98) 00072-7

Akpor, O.B. and Muchie, M. (2010). Remediation of heavy metals in drinking water and wastewater treatment systems: Processes and applications. International Journal of Physical Sciences, 5(12): 1807-1817.

Akpor, O.B., Ohiobor, G.O. and Olaolu, T.D. (2014). Heavy metal pollutants in wastewater effluents: sources, effects and remediation. Advances in Bioscience and $\quad$ Biotechnology, $2(4)$ 37-43, https://doi.org/10.11648/j.abb.20140204.11

Akinbile, C.O., Ogunrinde, T.A., Man, H.C.B. and Aziz, H.A. (2016). Phytoremediation of domestic wastewaters in free water surface constructed wetlands using Azolla pinnata. International Journal of Phytoremediation, 18: 54-61, https://doi.org/10.1080/15226514.2015.1058330

Albretsen, J. (2006). The toxicity of iron, an essential element. Vet Med- Bonner Springs Then Edwardsville 101(2): 82

Amaral, A., Cruz, J.V., Cunha, R.T.D. and Rodrigues, A. (2006). Baseline levels of metals in volcanic soils of the Azores (Portugal). Soil Sediment Contamination, 15(2): 123-130, https://doi.org/10.1080/15320380500506255

Argun, M.E., Dursun, S., Ozdemir, C. and Karatas, M. (2007). Heavy metal adsorption by modified oak sawdust: Thermodynamics and kinetics. Journal of Hazardous Material, 141: 77-85.
Arora, M., Kiran, B., Rani, S., Rani, A., Kaur, B. and Mittal, N. (2008). Heavy metal accumulation in vegetables irrigated with water from different sources. Food Chemistry, 111: 811-815, https://doi.org/10.1016/j.foodchem.2008.04.049

Arthur, E.L., Rice, P.J., Rice, P.J., Anderson, T.A., Baladi, S.M., Henderson, K.L. and Coats, J.R. (2005). Phytoremediation-an overview. Critical Reviews in Plant Sciences, 24(2): 109-122, https://doi.org/10.1080/07352680590952496

Ata, S., Moore, F. and Modabberi, S. (2009). Heavy metal contamination and distribution in the Shiraz Industrial Complex Zone Soil, South Shiraz, Iran. World Applied Sciences Journal, 6(3): 413-425

Aurangzeb, N., Nisa, S., Bibi, Y., Javed, F. and Hussain, F. (2014). Phytoremediation potential of aquatic herbs from steel foundry effluent. Brazilian Journal of Chemical Engineering, 31(4): 881-886, https://doi.org/10.1590/0104-6632.20140314s00002734

Ayandiran, T.A., Fawole, O.O., Adewoye, S.O. and Ogundiran, M.A. (2009). Bioconcentration of metals in the body muscle and gut of Clarias gariepinus exposed to sublethal concentrations of soap and detergent effluent. Journal of Cell and Animal Biology, 3(8): 113-118.

Baruah, S., Borgohain, J. and Sarma, K.P. (2014). Phytoremediation of arsenic by Trapa natans in a hydroponic system. Water Environment Research, 86: 422-432, https://doi.org/10.2175/106143013X13807328849972

Baker, A.J.M. (1995). Metal hyperaccumulation by plants: our present knowledge of the ecophysiological phenomenon. Will plants have a role in bioremediation 7-8.

Baldantoni, D., Alfani, A., Tommasi, D.P., Bartoli, G. and De Santo, A.V. (2004). Assessment of macro and microelement accumulation capability of two aquatic plants. Environmental Pollution, 130:149-156, https://doi.org/10.1016/j.envpol.2003.12.015

Baldantoni, D., Maisto, G., Bartoli, G. and Alfani, A. (2005). Analyses of three native aquatic plant species to assess spatial gradients of lake trace element contamination. Aquatic Botany, 83: 48-60.

Bañuelos, G.S., Ajwa, H.A., Mackey, B., Wu, L.L., Cook, C., Akohoue, S. and Zambrzuski, S. (1997). Evaluation of different plant species used for phytoremediation of high soil selenium. Journal of Environmental Quality, 26(3): 639-646, https://doi.org/10.2134/jeq1997.00472425002600030008

Becker, M. and Asch, F. (2005). Iron toxicity in rice-conditions and management concepts. Journal of Plant Nutrition and Soil Science, 168(4): 558-573, https://doi.org/10.1002/jpln.200520504

Berti, W.R. and Cunningham, S.D. (2000). Phytostabilization of metals. Phytoremediation of toxic metals: using plants to clean-up the environment. New York, John Wiley \& Sons. Inc 71-88.

Bharti, S. and Banerjee, T.K. (2012). Phytoremediation of the coalmine effluent. Ecotoxicology and Environmental Safety, 81: 36-42, https://doi.org/10.1016/j.ecoenv.2012.04.009

Bielicka, A., Bojanowska, I. and Wisniewski, A. (2005). Two Faces of ChromiumPollutant and Bioelement. Polish Journal of Environmental Studies, 14(1): 5-10.

Black, H. (1995). Absorbing possibilities: Phytoremediation. - Environ Health Prespect 103(12): 1106-1108.

Borowiak, K., Kanclerz, J., Mleczek, M., Lisiak, M. and Drzewiecka, K. (2016). Accumulation of $\mathrm{Cd}$ and $\mathrm{Pb}$ in water, sediment and two littoral plants (Phragmites australis, Typha angustifolia) of freshwater ecosystem. Archives of Environmental Protection, 42(3): 47-57.

Boyajian, G.E. and Carreira, L.H. (1997). Phytoremediation: A clean transition from laboratory to marketplace? Nature Biotechnology, 15(2): 127, https://doi.org/10.1038/nbt0297-127

Brooks, R.R. (1998). Plants that Hyperaccumulate Heavy Metals. CAB International, New York.

Cervantes, C., Campos-García, J., Devars, S., Gutiérrez-Corona, F., Loza-Tavera, H., Torres-Guzmán, J.C. and Moreno-Sánchez, R. (2001). Interactions of chromium with microorganisms and plants. FEMS Microbiology Reviews, 25 (3): 335-347

Chandra, P., Tripathi, R.D., Rai, U.N., Sinha, S. and Garg, P. (1993). Biomonitoring and amelioration of non-point source pollution in some aquatic bodies. Water Science \& Technology, 28: 323-326.

Chaudhry, T.M., Hayes, W.J., Khan, A.G. and Khoo, C.S. (1998). Phytoremediation focusing on accumulator plants that remediate metal- contaminated soils. Australasian Journal of Ecotoxicology, 4: 37-51.

Chen, C.W., Chen, C.F. and Dong, C.D. (2012). Distribution and accumulation of mercury in sediments of Kaohsiung River Mouth, Taiwan. APCBEE Procedia, 1: 153-158, https://doi.org/10.1016/j.apcbee.2012.03.025

Clinton, E.I., Ngozi, O.N. and Ifeoma, O.L. (2014). Heavy metals and polycyclic 
aromatic hydrocarbons in water and biota from a drilling waste polluted freshwater swamp in the mgbede oil fields of South-South Nigeria. Journal of Bioremediation and Biodegradation, 5(7): 1-6, https://doi.org/10.4172/2155-6199.1000258

Cushnie, G.C. (1985). Electroplating Wastewater Pollution Control Technology. Noyes Publication: New Jersey: pp. 375- 377.

Das, P., Samantaray, S. and Rout, G.R. (1997). Studies on cadmium toxicity in plants: a review. Environmental Pollution, 98(1): 29-36.

Davis, T.A., Volesky, B. and Vieira, R.H.S.F. (2000). Sargassum seaweed as biosorbent for heavy metals. Water Research, 34: 4270-4278, https://doi.org/10.1016/S0043-1354(00)00177-9

Degraeve, N. (1981). Carcinogenic, teratogenic and mutagenic effects of cadmium. Mutation Research, 86(1): 115-135, https://doi.org/10.1016/0165-1110(81)90035-X

Dikshit, A.K., Pallamreddy, K., Reddy, L.V.P. and Saha, J.C. (2000). Arsenic in ground water and its sorption by kimberlite tailings. Journal of Environmental Science and Health, Part A. Toxic/hazardous substances and environmental engineering, 35: 65-85, https://doi.org/10.1080/10934520009376955

Finocchio, E., Lodi, A., Solisio, C. and Converti, A. (2010). Chromium (VI) removal by methylated biomass of Spirulina platensis: the effect of methylation process. Chemical Engineering Journal, 156(2): 264-269, https://doi.org/10.1016/j.cej.2009.10.015

Garrido, S., Campo, D., Esteller, G.M., Vaca, M.V.R. and Lugo, J. (2005). Heavy metals in soil treated with sewage sludge composting, their effect on yield and uptake of broad bean seeds (Vicia faba L.). Water, Air, \& Soil Pollution, 166 (1-4): 303-319.

Gazsó, L.G. (2001). The key microbial processes in the removal of toxic metals and radionuclides from the environment. Journal of Occupational and Environmental Medicine, 7(3/4): 178-185.

Ghani, A. (2011). Effect of chromium toxicity on growth, chlorophyll and some mineral nutrients of Brassica juncea L. Egyptian Academic Journal of Biological Sciences, 2(1): 9-15.

Groten, J.P. and Bladeren, P.J.V. (1994). Cadmium bioavailability and health risk in food. Trends in Food Science \& Technology, 5(2): 50-55, https://doi.org/10.1016/0924-2244(94)90071-X

Guala, S.D., Vega, F.A. and Covelo, E.F. (2010). The dynamics of heavy metals in plant-soil interactions. Ecological Modelling, 221(8): 1148-1152, https://doi.org/10.1016/j.ecolmodel.2010.01.00

Gupta, M. and Chandra, P. (1998). Bioaccumulation and toxicity of mercury in rooted-submerged macrophyte Vallisneria spiralis. Environmental Pollution, 103(2-3): 327-332, https://doi.org/10.1016/S0269-7491(98)00102-X

Hänninen, H. and Lindström, K. (1979). Behavioral test battery for toxicopsychological studies: Used at the Institute of Occupational Health in Helsinki. Institute of Occupational Health.

Hayes, A.W. (1984). Principals and Methods in Toxicology NY: Raven Press.

Henry, J.R. (2000). In An Overview of Phytoremediation of Lead and Mercury. NNEMS Report. Washington D.C.; pp, 3-9.

Hinojosa, M.B., Carreira, J.A., García-Ruíz, R. and Dick, R.P. (2004). Soil moisture pre-treatment effects on enzyme activities as indicators of heavy metalcontaminated and reclaimed soils. Soil Biology and Biochemistry 36(10): 15591568, https://doi.org/10.1016/j.soilbio.2004.07.003

Horvat, T., Vidaković-Cifrek, Ž., Oreščanin, V., Tkalec, M. and Pevalek-Kozlina, B. (2007). Toxicity assessment of heavy metal mixtures by Lemna minor L. Science of the Total Environment, 384(1-3): 229-238, https://doi.org/10.1016/j.scitotenv.2007.06.007

Huang, S.H., Bing, P., Yang, Z.H., Chai, L.Y. and Zhou, L.C. (2009). Chromium accumulation, microorganism population and enzyme activities in soils around chromium-containing slag heap of steel alloy factory. Transactions of Nonferrous Metals Society of China 19(1): 241-248, https://doi.org/10.1016/S1003-6326(08)60259-9

Hughes, J.P., Polissar, L. and Belle, G.V. (1988). Evaluation and synthesis of health effects studies of communities surrounding arsenic producing industries. International Journal of Epidemiology, 17: 407-413, https://doi.org/10.1093/ije/17.2.407

INECAR (2000). Institute of Environmental Conservation and Research. Position paper against mining in Rapu-Rapu, published by INECAR, Ateneo de Naga University, Philippines. www.adnu.edu.ph/institutes/inecar/pospaper 1.asp, 2000

Ingole, N.W. and Bhole, A.G. (2003). Removal of heavy metals from aqueous solution by water hyacinth (Eichhornia crassipes). Journal of Water Supply Research and Technology, 52(2): 119-128.
Irfan, S. and AIAtawi, A. (2017). Eichhoria crassipes (Mart.) Solms. Application of Macrophyte in Heavy Metals Removal. Journal of Pure and Applied Microbiology, 11(4): 1737-1748.

Irfan, M., Hayat, S., Ahmad, A. and Alyemeni, M.N. (2013). Soil cadmium enrichment: Allocation and plant physiological manifestations. Saudi Journal of Biological Sciences, 20(1): 1-10, http://dx.doi.org/10.1016/j.sjbs.2012.11.004

Iwasaki, Y., Kagaya, T., Miyamoto, K.I. and Matsuda, H. (2009). Effects of heavy metals on riverine benthic macroinvertebrate assemblages with reference to potential food availability for drift-feeding fishes. Environmental Toxicology and Chemistry, 28(2): 354-363.

lyengar, V. and Nair, P. (2000). Global outlook on nutrition and the environment: meeting the challenges of the next millennium. Science of the Total Environment, 249: 331-346, https://doi.org/10.1016/S0048-9697(99)00529-X

Jadia, C.D. and Fulekar, M.H. (2008). Phytotoxicity and remediation of heavy metals by fibrous root grass (sorghum). Journal of Applied Biosciences, 10(1): 491499.

Jaishankar, M,. Mathew, B.B., Shah, M.S. and Gowda, K.R.S. (2014). Biosorption of Few Heavy Metal lons Using Agricultural Wastes. Journal of Environment Pollution and Human Health, 2(1): 1-6, https://doi.org/10.12691/jephh-2-1-1

Jaishankar, M., Tseten, T., Anbalagan, N., Mathew, B.B. and Beeregowda, K.N. (2014). Toxicity, mechanism and health effects of some heavy metals. Interdisciplinary Toxicology, 7(2): 60-72, https://doi.org/10.2478/intox-2014-0009

Jarup, L. (2003). Hazards of heavy metals contamination. British Medical Bulletin, 68: 167-182

Jordao, C.P., Nascentes, C.C., Cecon, P.R., Fontes, R.L.F. and Pereira, J.L. (2006). Heavy metal availability in soil amended with composted urban solid wastes. Environmental Monitoring and Assessment, 112(1-3): 309-326, https://doi.org/10.1007/s10661-006-1072-y

Khan, S., Cao, Q., Zheng, Y.M., Huang, Y.Z. and Zhu, Y.G. (2008). Health risks of heavy metals in contaminated soils and food crops irrigated with wastewater in Beijing, China. Environmental Pollution, 152: 686-692

Kooh, MR.R., Lim, L.B., Lim, L.H. and Dahri, M.K. (2016). Separation of toxic rhodamine $B$ from aqueous solution using an efficient low-cost material, Azolla pinnata, by adsorption method. Environmental Monitoring and Assessment, 188: 108, https://doi.org/10.1007/s10661-016-5108-7

Krämer, U. and Chardonnens, A. (2001). The use of transgenic plants in the bioremediation of soils contaminated with trace elements. Applied Microbiology and Biotechnology, 55(6): 661-672, https://doi.org/10.1007/s002530100631

Kumar, P., Dushenkov, V., Motto, H. and Raskin, I. (1995). Phytoextraction: the use of plants to remove heavy metals from soils. Environmental Science \& Technology, 29: 1232-1238.

Kumar, J.I.N., Soni, H. and Kumar, R.N. (2006). Biomonitoring of selected freshwater macrophytes to assess lake trace element contamination: a case study of Nal Sarovar Bird Sanctuary, Gujarat, India. Journal of Limnology, 65(1): 9-16.

Kumar, J.I.N., Soni, H., Kumar, R.N. and Bhatt, I. (2008). Macrophytes in phytoremediation of heavy metal contaminated water and sediments in Pariyej Community Reserve, Gujarat, India. Turkish Journal of Fisheries and Aquatic Sciences, 8(2): 193-200.

Kumar, V. and Thakur, R.K. (2017). Pollution load of SIDCUL effluent with reference to heavy metals accumulated in sediments using pollution load index (PLI) and geo-accumulation index (I-geo) at Haridwar (Uttarakhand), India. Journal of Environment and Bio-Sciences, 31(1): 163-168.

Kumar, V., Singh, J. and Chopra, A.K. (2017). Assessment of phytokinetic removal of pollutants of paper mill effluent using water hyacinth (Eichhornia crassipes [Mart.] Solms). Environmental Technology, 1-11, https://doi.org/10.1080/09593330.2017.1365944

Kumar, V., Singh, J., Pathak, V.V., Ahmad, S. and Kothari, R. (2017). Experimental and kinetics study for phytoremediation of sugar mill effluent using water lettuce (Pistia stratiotes L.) and its end use for biogas production. 3 Biotech, 7 (5): 330, https://doi.org/10.1007/s13205-017-0963-7

Kumar, V., Chopra, A.K., Singh, J., Thakur, R.K., Srivastava, S. and Chauhan, R.K. (2016). Comparative assessment of phytoremediation feasibility of water caltrop (Trapa natans L.) and water hyacinth (Eichhornia crassipes Solms.) using pulp and paper mill effluent. Archives of Agriculture and Environmental Science, 1(1): 13-21.

Kumar, V., Singh, J. and Kumar, P. (2019a). Heavy metal uptake by water lettuce (Pistia stratiotes L.) from paper mill effluent (PME): experimental and prediction modeling studies. Environmental Science and Pollution Research, 1-14. https://doi.org/10.1007/s11356-019-04766-2 9 
Kumar, V., Singh, J., Saini, A. and Kumar, P. (2019b). Phytoremediation of copper, iron and mercury from aqueous solution by water lettuce (Pistia stratiotes L.). Environmental Sustainability, 1-11, https://doi.org/10.1007/s42398-019-00050-8

Kumar, Y.P., King, P. and Prasad, V.S.R.K. (2006). Zinc biosorption on Tectona grandis Lf leaves biomass: equilibrium and kinetic studies. Journal of Chemical Engineering 124(1-3): 63-70.

Lakshman, G. (1987). Ecotechnological opportunities for aquatic plants, a survey of utilization options[M]. In: Aquatic Plants for Water Treatment and Resource Recovery (Reddy KR, Smith WH ed) Orlando, F.L.: Magnolia Publishing Inc. pp. 49-68.

Lambert, M., Leven, B.A. and Green, R.M. (2000). New methods of cleaning up heavy metal in soils and water. Environmental science and technology briefs for citizens. Kansas State University, Manhattan, KS. Available online at https:// cfpub.epa.gov/ncer_abstracts/index.cfm/fuseaction/display.files/filelD/14295

Li, Y.M., Chaney, R.L., Angle, J.S. and Baker, A.J.M. (2000). Phytoremediation of heavy metal contaminated soils. Journal of Environmental Quality, 837-858.

Lin, T.H., Huang, Y.L. and Wang, M.Y. (1998). Arsenic species in drinking water, hair, fingernails, and urine of patients with blackfoot disease. Journal of Toxicology and Environmental Health, Part A, 53: 85-93, https://doi.org/10.1080/009841098159376

Lone, M.I., He, Z.L., Stoffella, P.J. and Yang, X.E. (2008). Phytoremediation of heavy metal polluted soils and water: progresses and perspectives. Journal of Zhejiang University SCIENCE B, 9: 210-220, https://doi.org/10.1631/jzus.B0710633

Lu, X., Kruatrachue, M., Pokethitiyook, P. and Homyok, K. (2004). Removal of cadmium and zinc by water hyacinth, Eichhornia crassipes. ScienceAsia, 30(93): 103

Ma, L.Q., Komar, K.M., Tu, C., Zhang, W.H., Cai, Y. and Kennelley, E.D. (2001). A fern that hyperaccumulates arsenic. Nature, 409: 579, https://doi.org/ 10.1038/35054664

Mahurpawar, M. (2015). Effects of heavy metals on human health. International Journal of Research, 1-7.

Mandal, B.K. and Suzuki, K.T. (2002). Arsenic round the world: a review. Talanta 58 201-235, https://doi.org/10.1016/S0039-9140(02)00268-0

Meitei, M.D. and Prasad, M.N.V. (2016). Bioaccumulation of nutrients and metals in sediment, water, and phoomdi from Loktak Lake (Ramsar site), northeast India: phytoremediation options and risk assessment. Environmental monitoring assessment, 188(6): 329, https://doi.org/10.1007/s10661-016-5339-7

Mellem, J.J., Baijnath, H. and Odhav, B. (2012). Bioaccumulation of $\mathrm{Cr}, \mathrm{Hg}, \mathrm{As}, \mathrm{Pb}$, $\mathrm{Cu}$ and $\mathrm{Ni}$ with the ability for hyperaccumulation by Amaranthus dubius. African Journal of Agricultural Research, 7(4): 591-596, https://doi.org/10.5897/AJAR11.1486

Mishra, V.K., Upadhyay, A.R., Pathak, V. and Tripathi, B.D. (2008). Phytoremediation of mercury and arsenic from tropical opencast coalmine effluent through naturally occurring aquatic macrophytes. Water, Air, \& Soil Pollution, 192(1-4): 303-314, https://doi.org/10.1007/s11270-008-9657-4

Mohan Ram, H.Y. (1978). In vitro culture of aquatic flowering plants: achievements and prospects. Tenth P.R. White memorial lecture. Ahemdabad, India, 1-17.

Mueller, B., Rock, S., Gowswami, D. and Ensley, D. (1999). Phytoremediation Decision Tree. - Prepared by - Interstate Technology and Regulatory Cooperation Work Group; pp 1-36.

Nolan, K. (2003). Copper toxicity syndrome. Journal of Orthomolecular Psychiatry, 12(14): 270-282, https://doi.org/10.12691/env-3-1-1

Ojoawo, S.O., Udayakumar, G. and Naik, P. (2015). Phytoremediation of phosphorus and nitrogen with Canna $x$ generalis reeds in domestic wastewater through NMAMIT constructed wetland. Aquatic Procedia, 4: 349-356, https://doi.org/10.1016/j.aqpro.2015.02.047

Pathak, C., Chopra, A.K., Kumar, V. and Srivastava, S. (2010). Heavy metals contamination in waste-water irrigated agricultural soil near Bindal river, Dehradun, India. Pollution Research, 29(4): 583â.

Pathak, C., Chopra, A.K., Kumar, V. and Sharma, S. (2011). Effect of sewage-water irrigation on physico-chemical parameters with special reference to heavy metals in agricultural soil of Haridwar city. Journal of Applied and Natural Science, 3(1): 108113.

Patrick, L. (2002). Mercury toxicity and antioxidants: part i: role of glutathione and alpha-lipoic acid in the treatment of mercury toxicity-mercury toxicity. Toxicology and Applied Pharmacology, 7: 456-471.

Peng, K., Luo, C., Lou, L., Li, X. and Shen, Z. (2008). Bioaccumulation of heavy metals by the aquatic plants Potamogeton pectinatus $L$. and Potamogeton malaianus Miq. and their potential use for contamination indicators and in wastewater treatment. Science of the Total Environment, 392(1): 22-29, https://doi.org/10.1016/j.scitotenv.2007.11.032
Phippen, B., Horvath, C., Nordin, R. and Nagpal, N. (2008). Ambient water quality guidelines for iron: overview. Ministry of Environment Province of British Columbia.

Prakash, D., Verma, S., Bhatia, R. and Tiwary, B.N. (2011). Risks and precautions of genetically modified organisms. ISRN Ecology.

Prasad, S.M. and Singh, A. (2011). Metabolic responses of Azolla pinnata to cadmium stress: photosynthesis, antioxidative system and phytoremediation. Chemistry and Ecology, 27: https://doi.org/10.1080/02757540.2011.600695

Rai, P.K. and Tripathi, B.D. (2009). Comparative assessment of Azolla pinnata and Vallisneria spiralis in $\mathrm{Hg}$ removal from GB Pant Sagar of Singrauli Industrial region, India. Environmental Monitoring Assessment, 148: 75-84, https://doi.org/10.1007/s10661-007-0140-2

Rai, P.K. (2009). Microcosm investigation on phytoremediation of $\mathrm{Cr}$ using Azolla pinnata. International Journal of Phytoremediation, 12: 96-104, https://doi.org/10.1080/15226510902767155

Rai, P.K. (2009). Heavy metal phytoremediation from aquatic ecosystems with special reference to aquatic macrophytes. Critical Reviews in Environmental Science Technology, 39: 697-753, https://doi.org/10.1080/10643380801910058

Rai, P.K. (2008). Phytoremediation of $\mathrm{Hg}$ and $\mathrm{Cd}$ from industrial effluents using an aquatic free floating macrophyte Azolla pinnata. International Journal of Phytoremediation, 10: 430-439, https://doi.org/10.1080/15226510802100606

Rai, P.K. (2010). Phytoremediation of heavy metals in a tropical impoundment of industrial region. Environmental Monitoring Assessment, 165(1-4): 529-537, https://doi.org/ 10.1007/s10661-009-0964-z

Rai, P.K. and Tripathi, B.D. (2007). Heavy metals removal using nuisance blue green alga Microcystis in continuous culture experiment. Environmental Sciences, 4(1): 53-59, https://doi.org/10.1080/15693430601164956

Rascio, N. and Navari-Izzo, F. (2011). Heavy metal hyperaccumulating plants: how and why do they do it? And what makes them so interesting? Plant science, 180(2): 169-181, https://doi.org/10.1016/j.plantsci.2010.08.016

Raskin, I. and Ensley, B.D. (2000). Phytoremediation of Toxic Metals: Using Plants to Clean Up the Environment.- John Wiley \& Sons, Inc., New York.; pp 53-70.

Reilly, C. (1991). Metal contamination of food, 2nd edn. Elsevier Applied Science, London.

Rogers, E.E, Eide, D.J. and Guerinot, M.L. (2000). Altered selectivity in an Arabidopsis metal transporter. Proceedings of the National Academy of Sciences USA, 97(22): 12356-12360.

Roy, C.K., Jahan, M.A.A. and Rahman, S.S. (2018). Characterization and treatment of textile wastewater by aquatic plants (macrophytes) and algae. European Journal of Sustainable Development Research, 2(3): 29 , https://doi.org/10.20897/ejosdr/85933

Sadowsky, M.J. (1999). Phytoremediation: past promises and future practices. In Proceedings of the 8th international symposium on microbial ecology. Halifax Canada pp. 1-7.

Salt, D.E., Blaylock, M., Kunmar, N.P.B.A., Dushenkov, V., Ensley, B.D. and Chet, I. (1995). Phytoremediation: A novel strategy for the removal of toxic metals from the environment using plants. Nature Biotechnology, 13: 468-474, https://doi.org/10.1038/nbt0595-468.

Salt, D.E., Pickering, I.J., Prince, R.C., Gleba, D., Dushenkov, S., Smith, R.D. and Raskin, I. (1997). Metal accumulation by aquacultured seedlings of Indian Mustard. - Environ Science and Technology, 31(6): 1636-1644, https://doi.org/10.1021/es960802n

Santos, M.C.D. and Lenzi, E. (2000). The use of aquatic macrophytes (Eichhornia crassipes) as a biological filter in the treatment of lead contaminated effluents. Environmental Technology, 21(6): 615-622, https://doi.org/10.1080/09593330.2000.9618946

Sardar, K., Ali, S., Hameed, S., Afzal, S., Fatima, S., Shakoor, M.B. and Tauqeer, H.M. (2013). Heavy metals contamination and what are the impacts on living organisms. Greener Journal of Environment Management and Public Safety, 2(4): 172-179.

Satarug, S., Garrett, S.H., Sens, M.A. and Sens, D.A. (2011). Cadmium, environmental exposure, and health outcomes. Ciencia and saude coletiva, 16: 2587-2602, https://doi.org/10.1289/ehp.0901234

Sathawara, N.G., Parikh, D.J. and Agarwal, Y.K. (2004). Essential heavy metals in environmental samples from western India. Bulletin of Environmental Contamination and Toxicology, 73: 756-761, https://doi.org/10.1007/s00128-004-0490-1

Schultz, A., Jonas, U., Hammer, E. and Schauer, F. (2001). Dehalogenation of chlorinated hydroxybiphenyls by fungal laccase. Applied and Environmental Microbiology, 67(9): 4377-4381, https://doi.org/10.1128/AEM.67.9.4377-4381.2001 
Shallari, S., Schwartz, C., Hasko, A. and Morel, J.L. (1998). Heavy metals in soils and plants of serpentine and industrial sites of Albania. Science of the Total Environment, 209(2-3): 133-142.

Siciliano, S.D., Goldie, H. and Germida, J.J. (1998). Enzymatic activity in root exudates of Dahurian wild rye (Elymus dauricus) that degrades 2chlorobenzoic acid. Journal of Agricultural and Food Chemistry, (1): 5-7, https://doi.org/10.1021/jf9708195

Singh, J. and Kalamdhad, A.S. (2011). Effects of heavy metals on soil, plants, human health and aquatic life. International Journal of Research in Chemistry and Environment, 1(2): 15-21.

Singh, O.V., Labana, S., Pandey, G., Budhiraja, R. and Jain, R.K. (2003). Phytoremediation: an overview of metallic ion decontamination from soil. Applied Microbiology and Biotechnology, 61(5-6): 405-412, https://doi.org/10.1007/s00253-003-1244-4

Smith, C.J., Hopmans, P. and Cook, F.J. (1996). Accumulation of $\mathrm{Cr}, \mathrm{Pb}, \mathrm{Cu}, \mathrm{Ni}, \mathrm{Zn}$ and $\mathrm{Cd}$ in soil following irrigation with treated urban effluent in Australia. Environmental Pollution, 94(3): 317-323

Sobha, K., Poornima, A., Harini, P. and Veeraiah, K. (2007). A study on biochemical changes in the fresh water fish, Catla catla (Hamilton) exposed to the heavy metal toxicant cadmium chloride. Kathmandu University Journal of Science, Engineering and Technology, 3(2): 1-11.

Soliman, Z.I. (2006). A study of heavy metals pollution in some aquatic organisms in Suez Canal in Port-Said Harbour. Journal of Applied Sciences Research, 2(10): 657-663.

Sparks, D.L. (1995). Environmental Soil Chemistry. Academic Press, San Diego, CA.

Sprynskyy, M., Kosobucki, P., Kowalkowski, T. and Buszewski, B. (2007). Influence of clinoptilolite rock on chemical speciation of selected heavy metals in sewage sludge. Journal of Hazardous Materials, 149(2): 310-316, https://doi.org/10.1016/j.jhazmat.2007.04.001

Stern, B.R., Solioz, M., Krewski, D., Aggett, P., Aw, T.C., Baker, S., Crump, K., Dourson, M., Haber, L., Hertzberg, R., Keen, C., Meek, B., Rudenko, L., Schoeny, R., Slob, W. and Starr, T. (2007). Copper and human health: biochemistry, genetics, and strategies for modeling doseresponsem relationships. Journal of Toxicology and Environmental Health Part B, 10: 157-222.

Tang, S. and Willey, N.J. (2003). Uptake of 134 Cs by four species from the Asteraceae and two varieties from the Chenopodiaceae grown in two types of Chinese soil. Plant Soil, 250: 75-81, https://doi.org/10.1023/A:1022873930771

Taylor, G., Pahlsson, A.M., Benglsson, G., Baath, E. and Tranvik, L. (1989). Heavy metal ecology and terrestrial plant, microorganisms and invertebrates: A Review. Water, Air, \& Soil Pollution, 47: 189-215, https://doi.org/10.1007/BF00279327

Tijani, M.N., Onodera, S. and Adeleye, M.A. (2005). Environmental implications of adsorbed and total trace metals concentrations in bottom-sediments of an urban drainage network in a developing country. Materials and Geoenvironment, 52(1): 127.

Tobariya, S.K. (2015). Comparative Study of Physico-Chemical Parameters and Heavy Metal Detection in Agricultural Soil Irrigated By Sewage Water and Tube Well Water in Rewari City Rural. International Journal of Science and Research, 48-51.

Türkdogan, M.K., Fevzi, K., Kazim, K., Ilyas, T. and Ismail, U. (2003). Heavy metals in soil, vegetables and fruits in the endemic upper gastrointestinal cancer region of Turkey. Environmental Toxicology and Pharmacology, 13: 175-179, https://doi.org/10.1016/S1382-6689(02)00156-4

U.S.E.P.A. (1993). Standard Methods for the Examination of Water and Wastewater, American Public Health Association. US

U.S.E.P.A. (2001). A Citizen's Guide to Phytoremediation. US Environmental Protection Agency, Office of Solid Waste and Emergency Response. EPA-542-F-01-002.

Rulkens, W.H., Tichy, R. and Grotenhuis, J.T.C. (1998). Remediation of polluted soil and sediment: perspectives and failures. - Water Science \& Technology, 37: 27
-35, https://doi.org/10.1016/S0273-1223(98)00232-7

U.S.P.A. (2000). Introduction to Phytoremediation. EPA 600/R-99/107. U.S. Environmental Protection Agency, Office of Research and Development, Cincinnati, $\mathrm{OH}$.

Valko, M.M.H.C.M., Morris, H. and Cronin, M.T.D. (2005). Metals, toxicity and oxidative stress. Current Medicinal Chemistry, 12(10): 1161-1208.

Vara Prasad, M.N. and de Oliveira Freitas, H.M. (2003). Metal hyperaccumulation in plants: biodiversity prospecting for phytoremediation technology. Electronic Journal of biotechnology, 6(3): 285-321.

Wagner, G.J. (1993). Accumulation of cadmium in crop plants and its consequences to human health. Advances in Agronomy, 51: 173-212.

Wang, Q., Cui, Y. and Dong, Y. (2002). Phytoremediation of polluted waters potentials and prospects of wetland plants. Acta Biotechnologica, 22(1-2): 199-208, https://doi.org/10.1002/1521-3846

Wang, Y., Shi. J., Wang, H., Lin, Q., Chen, X. and Chen, Y. (2007). The influence of soil heavy metals pollution on soil microbial biomass, enzyme activity, and community composition near a copper smelter. Ecotoxicology and Environmental Safety, 67(1): 75-81, https://doi.org/10.1016/j.ecoenv.2006.03.007

Wei, C., Wang, C. and Yang, L. (2008). Characterizing spatial distribution and sources of heavy metals in the soils from mining-smelting activities in Shuikoushan Hunan Province, China. Journal of Environmental Sciences, 21 : 1230-1236.

Win, D.T., Than, M.M. and Tun, S. (2003). Lead removal from industrial waters by water hyacinth. AU Journal of Technology, 6(4): 187-192.

Yao, H., Xu, J. and Huang, C. (2003). Substrate utilization pattern, biomass and activity of microbial communities in a sequence of heavy metal-polluted paddy soils. Geoderma, 115(1-2): 139-148, https://doi.org/10.1016/S0016-7061(03)00083-1

Zaranyika, M.F. and Ndapwadza, T. (1995). Uptake of Ni, Zn, Fe, Co, Cr, Pb, Cu and $\mathrm{Cd}$ by water hyacinth (eichhornia crassipes) in mukuvisi and manyame rivers, Zimbabwe. Journal of Environmental Science and Health, Part A, 30(1): 157169, https://doi.org/10.1080/10934529509376193

Zayed, A., Gowthaman, S. and Terry, N. (1998). Phytoaccumulation of trace elements by wetland plants: I. Duckweed. Journal of Environmental Quality, 27 (3): 715-721, https://doi.org/10.2134/jeq1998.00472425002700030032x

Zayed, A.M. and Terry, N. (2003). Chromium in the environment: factors affecting biological remediation. Plant Soil, 249(1): 139-156, https://doi.org/10.1023/A:1022504826342

Zhang, X.B., Peng, L.I.U., Yang, Y.S. and Chen, W.R. (2007). Phytoremediation of urban wastewater by model wetlands with ornamental hydrophytes. Journal of Environment Science, 19(8): 902-909, https://doi.org/10.1016/S1001-0742(07)60150-8

Zhu, Y.L., Zayed, A.M., Qian, J.H., De Souza, M. and Terry, N. (1999). Phytoaccumulation of trace elements by wetland plants: II. Water hyacinth. Journal of Environmental Quality, 28(1): 339-344, https://doi.org/10.2134/jeq1999.00472425002800010042x

Zinicovscaia, I., Duca, G., Cepoi, L., Chiriac, T., Rudi, L., Mitina, T., Frontasyeva, M.V., Pavlov, S. and Gundorina, S.F. (2015). Biotechnology of metal removal from industrial wastewater: zinc case study. Clean-Soil Air Water, 42(1): 112-117, https://doi.org/10.1002/clen.201200570

Zinicovscaia, I., Yushin, N., Shvetsova, M. and Frontasyeva, M. (2018). Zinc removal from model solution and wastewater by Arthrospira (Spirulina) Platensis biomass. International Journal of Phytoremediation, 20(9): 901-908, https://doi.org/10.1080/15226514.2018.1448358

Zurayk, R., Sukkariyah, B., Baalbaki, R. and Ghanem, D.A. (2001). Chromium phytoaccumulation from solution by selected hydrophytes. International Journal of Phytoremediation, 3: 335-350, https://doi.org/10.1080/15226510108500063 